\title{
ON A COLLECTION OF FISHES MADE BY P. O. SIMONS IN ECUADOR AND PERU.
}

\author{
By Edwin Chapin Starks, \\ of Stanford University, California.
}

The collection on which this paper is based includes both marine and fresh-water species, and was made by the late Mr. P. O. Simons, in Ecuador and Peru, during the winter of 1898 and 1899.

With one or two exceptions the marine fishes were collected at Guayaquil, Ecuador, and Callao, Peru. They illustrate very well the faunal relations of these localities. Guayaquil lies about equidistant between Panama and Callao, but belongs distinctly to the faunal region of Panama and northward.

All of the 44 species that were taken at Guayaquil are also found at Panama, with the exception of three species described as new from Guayaquil and one species of the southern fauna not extending north of Guayaquil (mentioned below). Sixteen of these have not been taken north of Panama and 24 extend their range to the Gulf of California.

Of the 34 species collected at Callao 23 have not been taken farther north, 11 have been taken north to the Gulf of California, and the other one not north of Guayaquil.

Thus it appears that with a single exception the fishes extending their range north of Callao are species of wide distribution. Five of the eleven can not perhaps fairly be considered in this connection. Sphyrna zygæna, Scomber japonious, Sarda chilensis, Caulolatitus princeps are of such very wide distribution, and Anisotremus scapularis was, with little doubt, erroneously reported from Mexico.

The species of Guayaquil are in all cases very much darker than the same species from Panama, making it appear probable that the faunas of these two localities, though similar, do not intermingle.

The drawings for this paper were made by Chloe Lesley Starks. 
Table of distribution.

\begin{tabular}{|c|c|c|c|c|}
\hline Name. & $\begin{array}{c}\text { Callao, } \\
\text { Peru. }\end{array}$ & $\begin{array}{l}\text { Guaya- } \\
\text { quil, } \\
\text { Ecuador. }\end{array}$ & Panama. & $\begin{array}{c}\text { Gulf of } \\
\text { Califor- } \\
\text { nia. }\end{array}$ \\
\hline Carcharias azureus. & & $x$ & $x$ & . \\
\hline 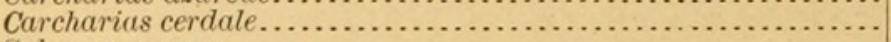 & & $\hat{x}$ & & \\
\hline 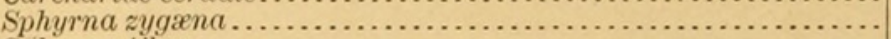 & $x$ & $x$ & $x$ & $x$ \\
\hline 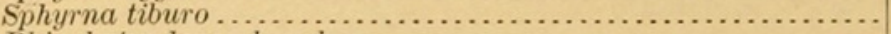 & & $x$ & $x$ & $x$ \\
\hline 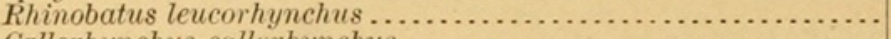 & & $x$ & $x$ & $x$ \\
\hline 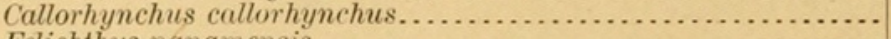 & $\times$ & & & \\
\hline 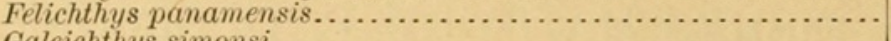 & 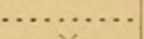 & $x$ & $x$ & $x$ \\
\hline 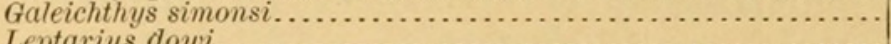 & . $x$ & & & \\
\hline 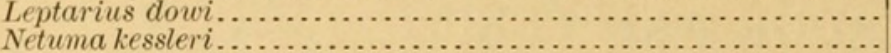 & $\cdots \cdots$ & $x$ & $x$ & \\
\hline $\begin{array}{l}\text { Netuma kessleri } \\
\text { Tachysurus equatorialis } \ldots \ldots \ldots \\
\ldots\end{array}$ & $\ldots \ldots$ & $x$ & $\times$ & \\
\hline 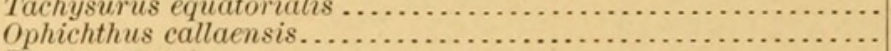 & $\cdots \cdots$ & $\frac{x}{x}$ & $\cdots \cdots$ & \\
\hline Elops saurus & & $\begin{array}{l}x \\
x\end{array}$ & & \\
\hline 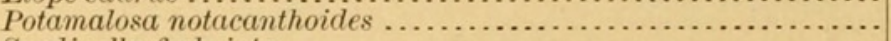 & $x$ & & & \\
\hline 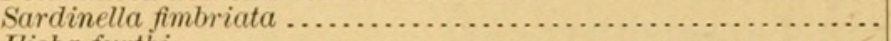 & $x$ & & & \\
\hline 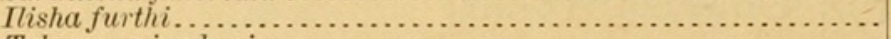 & $\ldots \ldots \ldots \ldots$ & $x$ & $x$ & $\ldots$ \\
\hline 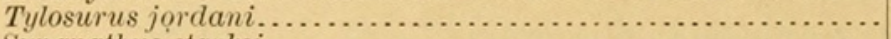 & $\cdots$ & $x$ & & \\
\hline 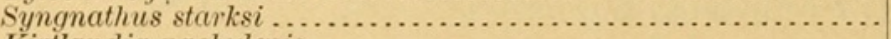 & & $x$ & …. & $x$ \\
\hline 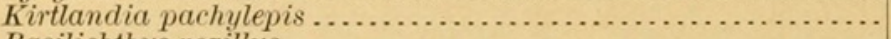 & & $x$ & × & . \\
\hline 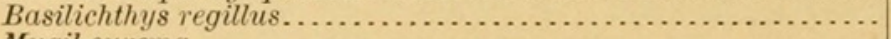 & $\times$ & & & \\
\hline 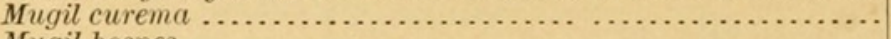 & ........... & $x$ & $x$ & $x$ \\
\hline 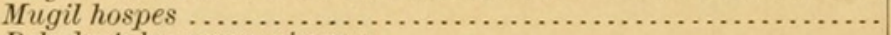 & $\cdots$ & $x$ & $x$ & $x$ \\
\hline 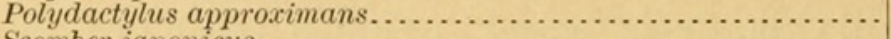 & . $x$ & $x$ & $x$ & $x$ \\
\hline 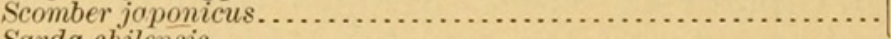 & $\times$ & & & $x$ \\
\hline 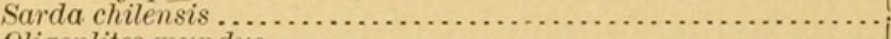 & $x$ & $x$ & $\times$ & $x$ \\
\hline 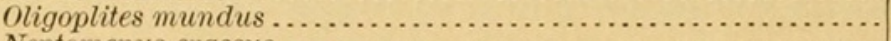 & ... & $\times$ & $x$ & $x$ \\
\hline 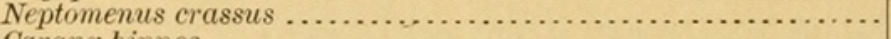 & 然 & & & \\
\hline 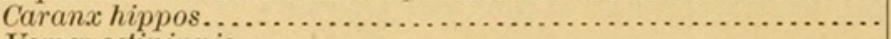 & .......... & $x$ & $x$ & K \\
\hline 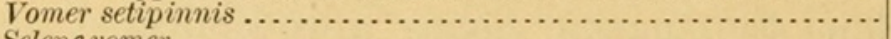 & $\times$ & $x$ & $x$ & r \\
\hline 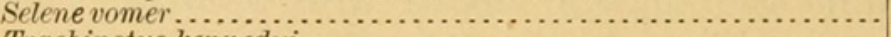 & $\cdots \cdots \cdot$ & $x$ & $x$ & K \\
\hline 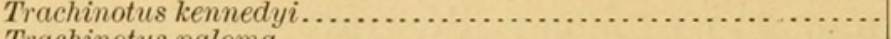 & $\cdots \cdots$ & $\times$ & $x$ & $x$ \\
\hline 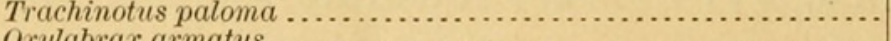 & $x$ & $\cdots$ & $x$ & $x$ \\
\hline 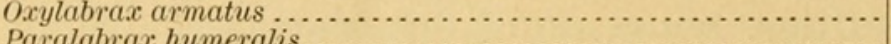 & & $x$ & $x$ & $\cdots$ \\
\hline 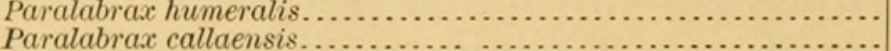 & $x$ & & & \\
\hline $\begin{array}{l}\text { Paralabrax callaensis } \ldots \ldots \ldots \\
\text { Lutianus argentiventris } \ldots \ldots \\
.\end{array}$ & $x$ & $\cdots$ & & \\
\hline 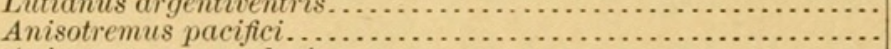 & & $x$ & $x$ & \\
\hline 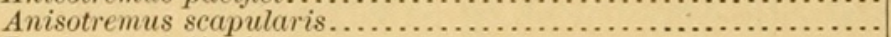 & $\ddot{x}$ & & $x$ & $\cdots$ \\
\hline 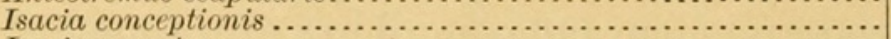 & $x$ & . & & $a_{>}$ \\
\hline 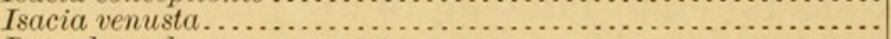 & $\hat{x}$ & $\ldots \ldots$ & . & \\
\hline 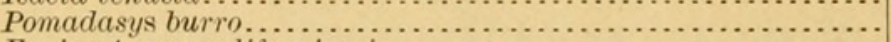 & $\cdots$ & $x$ & & \\
\hline 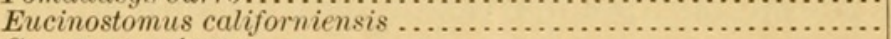 & $\cdots$ & $\hat{x}$ & $x$ & $x$ \\
\hline 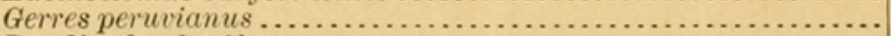 & $x$ & $x$ & $x$ & \\
\hline 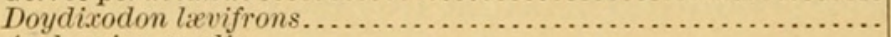 & $x$ & . & & \\
\hline 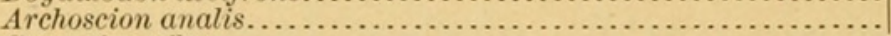 & $x$ & & & \\
\hline 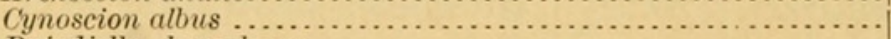 & $\begin{array}{l}\cdots \\
\end{array}$ & $x$ & $x$ & \\
\hline 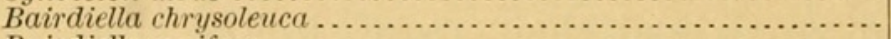 & .. & $x$ & $x$ & \\
\hline 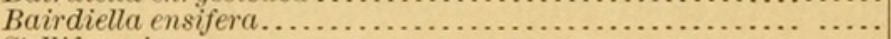 & & $x$ & $x$ & \\
\hline 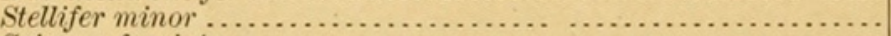 & $x$ & $\ldots \ldots$ & $\ldots \ldots$ & \\
\hline 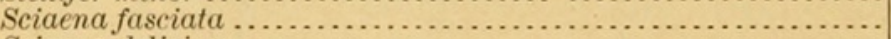 & $x$ & $\ldots .$. & ...... & \\
\hline 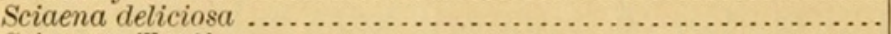 & $x$ & ........ & $\ldots \ldots$ & \\
\hline 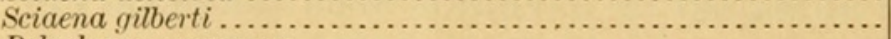 & $x$ & $\ldots \ldots \ldots$ & $\ldots \ldots$ & $\ldots \ldots$ \\
\hline 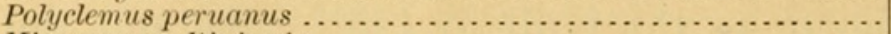 & $x$ & $\ldots \ldots \ldots$ & $\cdots$ & .... \\
\hline 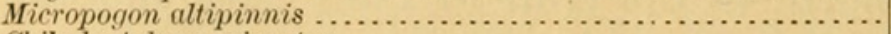 & .. & $\times$ & $\times$ & \\
\hline 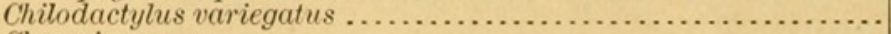 & $\times$ & .. & & \\
\hline 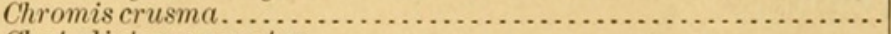 & $x$ & ... & & \\
\hline 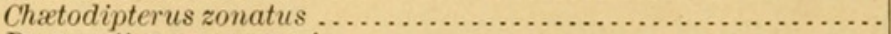 & ........ & $x$ & $x$ & $x$ \\
\hline 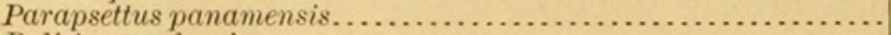 & 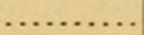 & $x$ & $x$ & \\
\hline 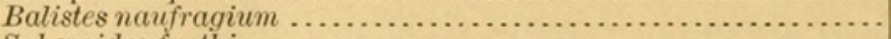 & 0 & $x$ & x & $x$ \\
\hline 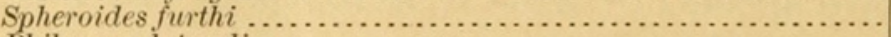 & ... & $x$ & $x$ & \\
\hline 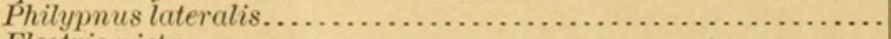 & $x$ & $x$ & x & \\
\hline 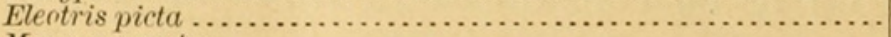 & * & $x$ & $x$ & \\
\hline 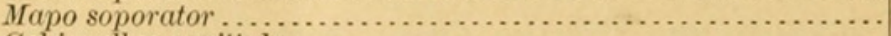 & $x$ & $x$ & $x$ & \\
\hline 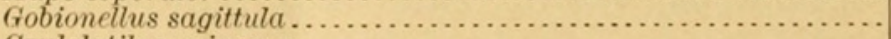 & & $x$ & $x$ & \\
\hline 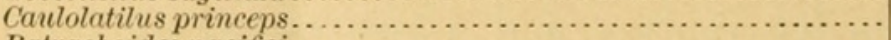 & $x$ & & & \\
\hline 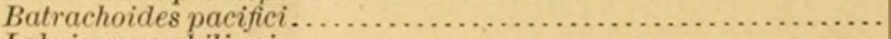 & $\cdots$ & & $x$ & $\cdots$ \\
\hline 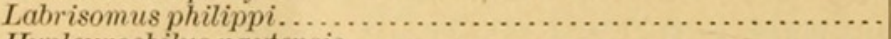 & $x$ & $\cdots \cdots$ & $\cdots$ & $\cdots$ \\
\hline 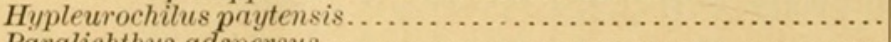 & $x$ & 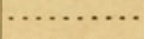 & $\cdots \cdots$ & $\cdots \cdots$ \\
\hline 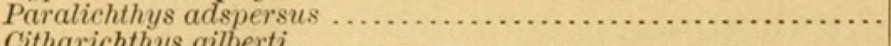 & & $\cdots \cdots \cdots$ & $\cdots$ & \\
\hline 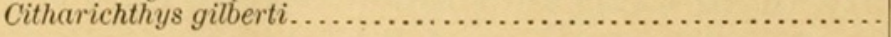 & & & & \\
\hline
\end{tabular}


The following ten species are here described as new.

\begin{tabular}{|c|c|c|c|}
\hline Name. & $\begin{array}{l}\text { U.S. N.M. } \\
\text { type } \\
\text { number. }\end{array}$ & Name. & $\begin{array}{l}\text { U.S. N. M. } \\
\text { type } \\
\text { number. }\end{array}$ \\
\hline 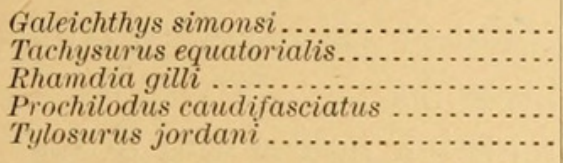 & $\begin{array}{r}53466 \\
53470 \\
53472 \\
53473 \\
53469\end{array}$ & 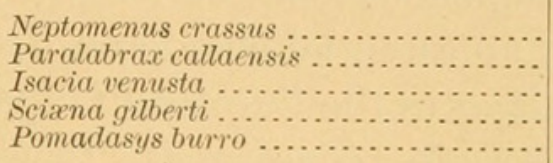 & $\begin{array}{l}53465 \\
53471 \\
53467 \\
53464 \\
53468\end{array}$ \\
\hline
\end{tabular}

Family GALEID FE.

I. CARCHARIAS AZUREUS Gilbert and Starks.

A specimen considerably larger than the type, and agreeing with it very well in all essential characters, was collected at Guayaquil, Ecuador. It was preserved in alcohol as a partially skinned specimen. As in the type, the claspers are undeveloped and fail to reach to the posterior margin of the ventral fins.

\section{CARCHARIAS CERDALE (Gilbert).}

Three small specimens from Guayaquil agree very well with the typical specimens from Panama.

\section{Family SPHYRNID A.}

3. SPHYRNA ZYGÆNA (Linnæus).

One specimen from Callao, Peru.

\section{SPHYR NA TIBURO (Linnæus).}

A specimen collected at Guayaquil, Ecuador. Although this species was not reported from the Pacific until 1895, it appears to be as common as $S$. tudes, and will probably be found to have as wide a range, at least in American waters.

\section{Family RHINOBATID AE.}

\section{RHINOBATUS LEUCORHYNCHUS (Günther).}

A specimen $43 \mathrm{~cm}$. in length from Guayaquil, Ecuador. It differs from a specimen from Panama, $38 \mathrm{~cm}$. in length, in having the snout more blunt, the rostral ridges not so narrow, and the lateral edge of disk a little more concave. In all of these respects about intermediate between the Panama specimen and a specimen of $R$. glaucostigma from Mazatlan, $57 \mathrm{~cm}$. long. It has no trace, however, of the characteristic slate-colored spots on the back or the dark blotch under the tip of the snout of R. glaucostigma. Both specimens of $R$. lencorhynchus have the dorsals darker than in $R$. glaucostigma, and the shagreen appears to be a little rougher and coarser. 


\section{Family CHIM ERID E.}

\section{CALLORHYNCHUS CALLORHYNCHUS Linnæus.}

A specimen $67 \mathrm{~cm}$. in length was collected at Callao, Peru. It differs in no essential characters from a specimen of this species from New Zealand in the Stanford University collections.

Body strongly compressed, twice as high as thick below first dorsal spine, where it is one-fourth of entire length to base of upper caudal lobe. Body thence tapering rapidly back to the rather slender caudal peduncle. Upper anterior profile forming an even, moderate curve to a point in front of and on a level with eye, where it is very slightly produced. Eye contained $3 \frac{3}{4}$ times in the space obliquely upward from its posterior margin to base of dorsal spine, and situated midway between dorsal spine and tip of snout (without rostral process). Dental plates agreeing well with the picture published by Garman. ${ }^{a}$

Front of pectoral one diameter of eye behind front of dorsal spine. Base of first dorsal contained $2 \frac{3}{4}$ times in space between dorsals; base of second dorsal equal to this space and equal to depth of body under dorsal spine. Posterior end of base of ventral under front of second dorsal. Tip of pectoral when fin is held close to body reaches to posterior end of ventral base.

Color dark silvery with large, obscure, dark, round blotches on upper part of side and back; one series of these along lateral line and traces of one below. A broken, dark band connects the dorsals and is separated from its fellow of the opposite side by a light streak on median line of back. A large, dusky blotch below eye; one on each side of dorsal spine; one on opercular region, and one above base of ventral. Fins all dark. These markings are all more conspicuous on the New Zealand specimen.

\section{Family SILURIDA.}

\section{FELICHTHYS PANAMENSIS (Gill).}

A specimen $20 \mathrm{~cm}$. in length from Guayaquil differs from specimens from Panama only in having the barbels a little longer and the dorsal shield a little wider and more deeply sculptured. The width of the dorsal shield measured from side to side, without considering the transverse curve of the back, is one-third of the length of the head. The maxillary barbel reaches to the middle of the ventrals; the pectoral filament to the middle of the anal.

\section{GALEICHTHYS SIMONSI, new species.}

Head, $3 \frac{1}{3}$ in length without caudal; depth, 5 . Eye, $6 \frac{1}{5}$ in head; snout, $2 \frac{5}{6}$; width between angles of mouth, $2 \frac{1}{3}$; width of head, $1 \frac{2}{5}$; dorsal spine, $1 \frac{6}{7}$; first dorsal ray, $1 \frac{3}{5}$; pectoral spine, $1 \frac{5}{6}$; ventral fin, $2 \frac{1}{2}$; long- 
est anal ray, $2 \frac{1}{5}$; base of adipose dorsal, 4 ; depth of caudal peduncle, 4. Dorsal, I, 6; anal, 16.

Upper anterior profile nearly straight to above eyes, thence slightly convex to tip of snout. Top of head more evenly granular than in $G$.

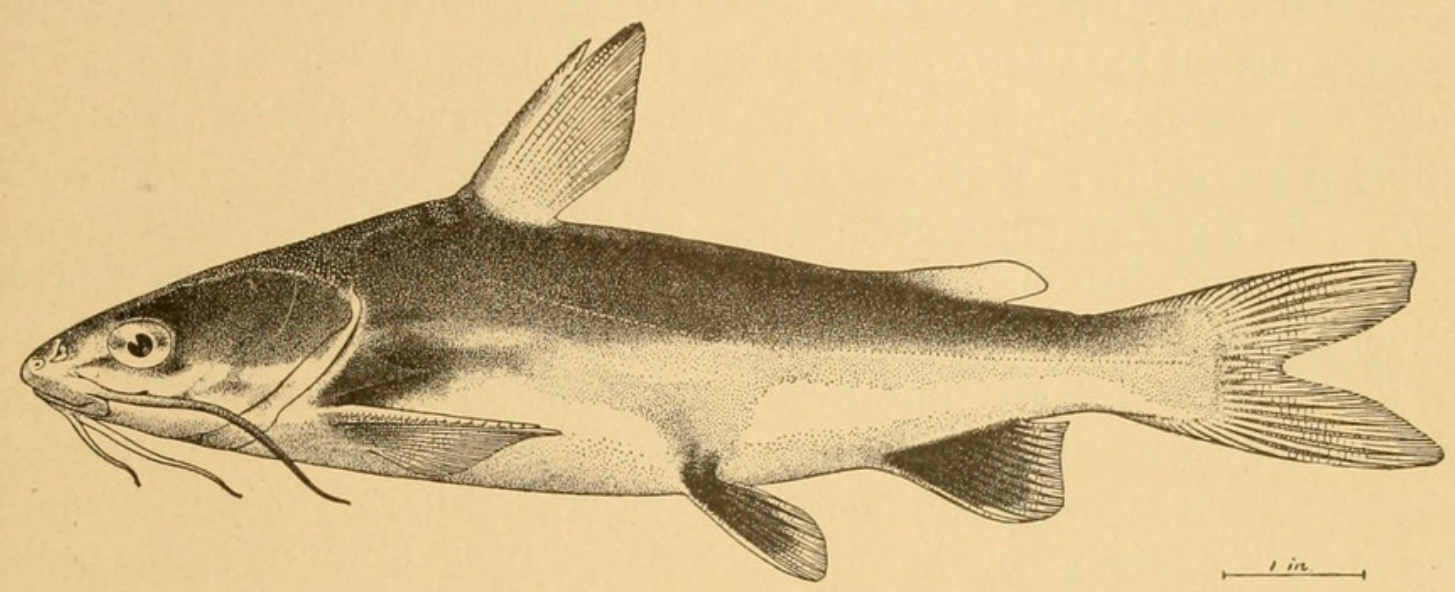

Fig. 1.-GaLeichthys SIMONSI.

jordani, the granulated area not irregularly striated anteriorly and extending farther forward, or to above front of pupil in the usual two diverging points. Fontanel groove reaching to within half a diameter of the eye oi the occipital process. The groove tapers at both ends, and is not wider anteriorly; at its middle, where it enters the granulated area, it is slightly constricted. The ridge of the occipital process

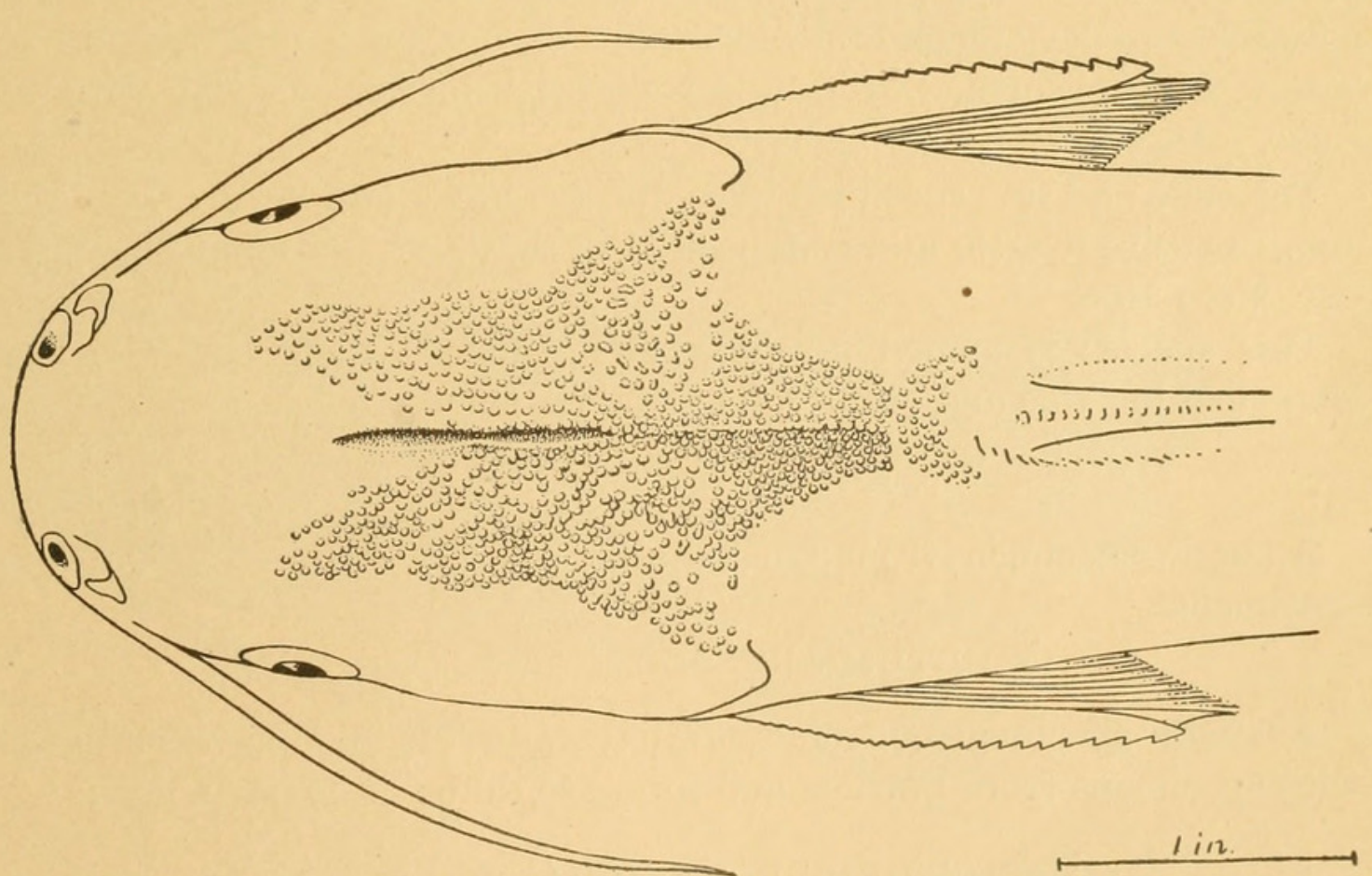

Fig. 2.-Galeichthys simonsi.

is not so sharp and high, the sides more gently sloping than in G. jorpani; the width of the process equals its length. The snout, as viewed from above, is more truncate than in G.jordani; the eye is a little larger. The palatine patches of teeth are smaller, more diverging, and 
voL. $\mathrm{xxx}$.

not so nearly rounded; the width of each patch is half its length. The vomerine patches are not separated, though notched at the median line before and behind.

Maxillary barbel reaching just past base of pectoral spine, not quite to pectoral pore; postmental barbels to edge of branchiostegal membrane; mental barbels two-thirds of the distance from their base to edge of branchiostegal membrane. Pectoral pore very small. Humeral spine more slender than in G.jordani, and more concave on upper edge, making its point more acute. Gill rakers, $5+10$.

Color very dark brown, nearly black on upper parts; lower parts silvery white. The dark color of back gradually changing to the white of lower parts on body, but on anterior part of head the dark color extends down to a little below eye and changes abruptly to white; the change is more gradual on opercular region. A large black spot just behind gill opening covers humeral spine. Base of dorsal spine dark, the rest of the fin pale, adipose dorsal dusky only at base. A jet black blotch covers nearly the entire anal fin, beginning sharply at the base of the fin in strong contrast with the pure white of body just above, leaving a narrow light border along the anterior edge of fin, and a broader one across tips of rays. A similar spot on ventrals, but diffused upward into the silvery white of belly, extending farther toward tips of rays on upper surface of fin than on lower. Upper surface of pectoral dark at base of rays, becoming lighter toward ends of rays, not nearly so dark as on other lower fins except on a small region at base. Lower surface of pectoral slightly dusky. Caudal without color. Maxillary barbel black.

The type and sole specimen was collected at Callao, Peru. It is 255 $\mathrm{mm}$. in entire length, and is deposited in the U. S. National Museum, Cat. No. 53466.

This species is named for Mr. P. O. Simons, whose life was lost while making this and other collections in South America.

\section{LEPTARIUS DOWI Gill.}

A single specimen from Guayaquil does not differ from Panama specimens.

\section{ro. NETUMA KESSLERI (Steindachner).}

A single specimen collected at Guayaquil. It has been compared with specimens from Panama and found to differ in no particular.

\section{TACHYSURUS EQUATORIALIS, new species.}

Head, $3 \frac{9}{10}$ in length to base of caudal; depth, $5 \frac{2}{5}$. Eye, 5 in head; snout, 3 ; width between angles of mouth, 3 ; width of head, $1 \frac{1}{2}$, length of dorsal spine, $1 \frac{1}{2}$; first dorsal ray, $1 \frac{1}{4}$; first pectoral ray, $1 \frac{3}{5}$; ventral fin, $1 \frac{5}{6}$; longest anal ray, 2 ; base of adipose dorsal, 3 ; depth of caudal peduncle, 3. Dorsal, I, 6; anal, 23. 
Upper anterior profile appearing perfectly straight, and rather steeply sloping from the dorsal spine nearly to the tip of the snout, where it curves very slightly downward. Head as viewed from the

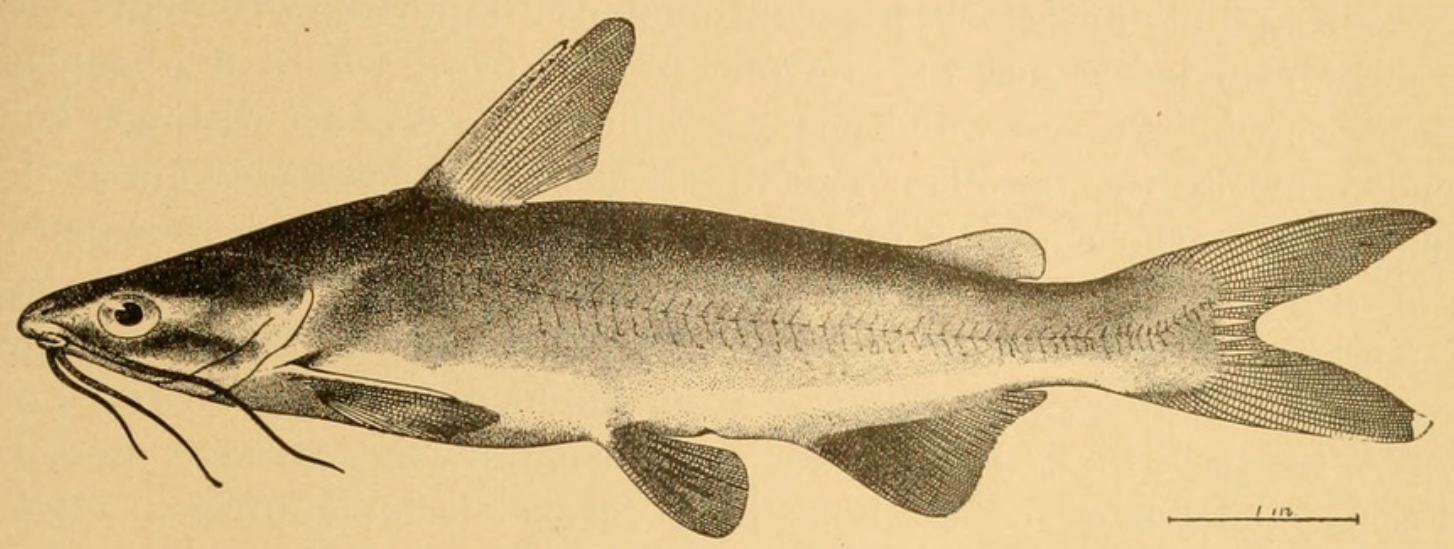

Fig. 3.-TAChysurus equatorialis,

side sharply wedge-shaped. Top of head very finely granular; the granulated area ends some distance behind the eyes, but is continued forward to a point on each side, as a slightly rugose surface covered by

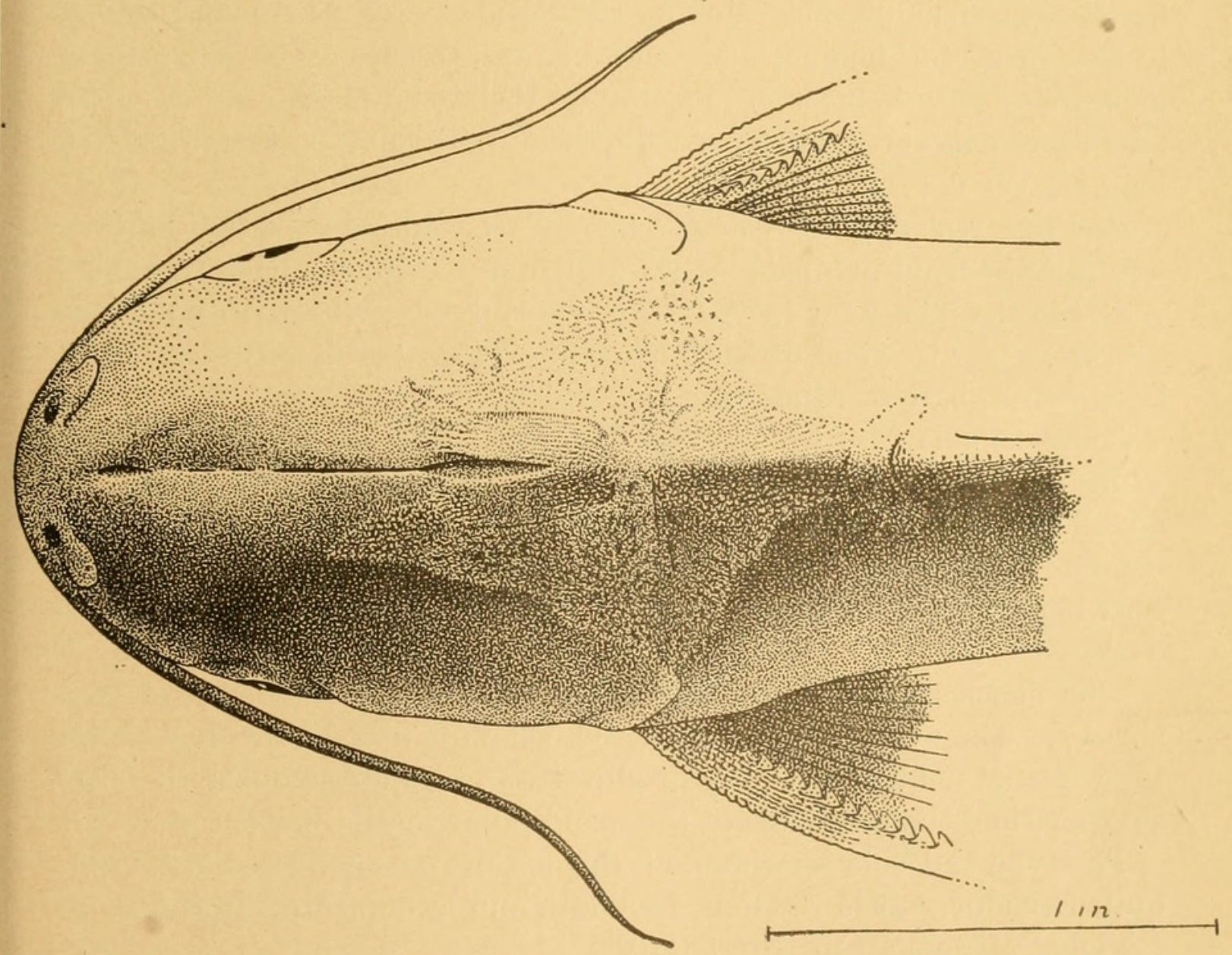

Fig. 4.-TACHYSURUS EQUATORIALIS.

thin skin, to opposite the posterior margin of the eyes. The fontanel groove fails to reach the occipital process by a distance equal to the vertical diameter of the eye; its widest and deepest part is where it 
traverses the granulated area on top of head, where for a distance equal to the long diameter of the eye it is sharply defined, and as wide and deep as the base of the slender maxillary barbel. Posteriorly it ends in a point; anteriorly it is continued as a faint line with indefinite gently rounded edges to in front of the eyes, where it abruptly becomes wider, deeper, and sharply defined for a short distance and ends opposite the posterior nostril. Occipital process as wide as its length with the addition of the median length of the very narrow dorsal plate. The keel of the occipital process is sharp and high, with a slightly concave area on each side of it; at a little behind the middle of its length its sides slope away from the median keel at an angle of $45^{\circ}$. Snout as viewed from above rather narrow and evenly rounded. Premaxillary band of teeth as long as eye and one-fifth as wide; palatine patches small, elliptical, and widely separated, each bearing about 30 bluntly rounded teeth; length of each patch two-fifths of length of eye and half as wide as long. Posterior, median, mandibular teeth not enlarged as in other species. Eye large; scarcely above level of mouth; the beginning of its posterior fifth at middle of length of head. Maxillary barbel reaching to axillary pore; postmental barbel to base of pectoral spine; and mental barbel to base of branchiostegal membrane. Branchiostegal membrane forming a fold across isthmus. Gill rakers rather long and slender; those near angle of arch half as long as eye; $6+13$ in number.

Pectoral reaching to opposite base of last dorsal ray; the ventrals not quite to front of anal. Anal high anteriorly; its posterior edge very slightly concave; its last ray coterminous with tip of adipose dorsal. Posterior end of base of adipose dorsal two-thirds of head's length from base of caudal rays.

Color very dark brown above, changing gradually on sides to dirty white on lower parts; head dark to below eye; barbels all black; dorsal and adipose dorsal dusky; anterior half of anal growing lighter behind; upper surface of ventral and pectoral blue black; the former growing lighter toward ends of rays; their lower surface dusky; caudal dusky.

This species appears to be related to $T$. steindachneri, but not closely. The eye is much larger, the occipital process much sharper, the fontanel not so large; the profile straighter and steeper; the head sharper; and the character of the mandibular teeth different.

The type and sole specimen of this species was collected at Guayaquil, Ecuador. It is $193 \mathrm{~mm}$. in length and is deposited in the U. S. National Museum, Cat. No. 53470. 
12. RHAMDIA GILLI, new species.

Plate LXV, fig. 1.

Head, 4 to $4 \frac{1}{5}$ in length without caudal; depth, $4 \frac{1}{2}$ to $4 \frac{3}{4}$. Eye, 5 in head; interorbital space, 3 ; bony part of interorbital space, $3 \frac{3}{4}$; width between angles of mouth, 3 ; width of head, $1 \frac{1}{4}$; dorsal spine, $1 \frac{2}{5}$; longest dorsal ray, $1 \frac{1}{4}$; pectoral spine, $1 \frac{3}{5}$; longest pectoral ray, $1 \frac{2}{5}$; longest ventral ray, $1 \frac{3}{4}$; base of dorsal, $1 \frac{4}{5}$; base of anal, 2 ; length of upper caudal lobe, 1 ; length of median caudal rays, 2 ; depth of caudal peduncle, 2. Dorsal, I, 6 ; anal, 11; ventral, 6.

Occipital process long and narrow, failing to reach the dorsal buckler by a space equal to half a diameter of pupil. Fontanel extending behind eye a distance equal to $1 \frac{1}{2}$ times diameter of eye. Its posterior portion separated from its anterior by a narrow bridge of bone opposite the posterior margin of eye. Snout rather narrow, and projecting slightly beyond tip of mandible; equal in length to postorbital part of head. Eye at middle of length of head and having a free border. Width of premaxillary band of teeth one-fourth its length; the band is not interrupted at its middle. Maxillary barbel reaching just past base of ventrals; mental barbel to base of pectoral fin; and postmental barbel to middle of pectoral spine.

Distance from tip of snout to insertion of dorsal contained $2 \frac{3}{4}$ times in length to base of caudal. Dorsal spine ending in a short ray-like filament that does not,reach to tips of soft rays. When dorsal is reclined, the tips of its rays just fail to reach the front of adipose dorsal. The adipose dorsal is a very thin, high, fold of skin on a raised pedicle; its length contained $3 \frac{1}{2}$ times in the body length, and its height from the pedicle is one-fourth of length of head. The posterior end of its base is a little behind the tips of the anal rays, and it projects backward in a rounded lobe considerably beyond its base. The pectoral rays extend beyond the pectoral spine to below the base of the first dorsal ray. The ventrals extend two-thirds of the distance from their base to front of anal. Anal fin rounded behind, the distance from its base to base of median caudal rays is equal to length of head less half the diameter of eye. Upper lobe of caudal sharp and longer than the lower rounded lobe by a diameter of eye. Vent opposite middle of length of ventral rays.

Color dark brown with a diffused, rather wide, light band following lateral line; a large dark spot on opercle; fins all dusky; a dark line on membrane before each dorsal ray; adipose dorsal darker toward outer edges; anterior edge of maxillary barbel white, contrasting strongly with dark posterior edge; other barbels colorless.

This species seems to be more closely related to Rhamdia jenynsii (Günther) than to any other. It differs in having a larger head, a

Proc. N. M. vol. $\mathrm{xxx}-0 \mathrm{~B}-49$ 
much greater depth, a shorter anal, shorter maxillary barbels, and a light, rather than a dark, lateral band.

The type and one cotype were taken at Eten, Peru, in the Rio Eten. The type is $155 \mathrm{~mm}$. in entire length and the cotype 110. The latter is deposited in the U. S. National Museum, Cat. No. 53472; the cotype in Stanford University Museum.

I take pleasure in naming this species for Dr. Theodore Gill.

\section{CETOPSIS OCCIDENTALIS Steindachner.}

Four specimens were taken at Guayaquil, the type locality of the species. They are from 16 to $26 \mathrm{~cm}$. in length.

They agree very well with Dr. Steindachner's description of the type specimen except that the teeth on the vomer are in a single row anteriorly, and a double row posteriorly. In the type specimen they are said to be in a double row anteriorly and a triple row posteriorly.

\section{Family PYGIDIIDA. \\ I4. PYGIDIUM DISPAR Tschudi.}

A single specimen $18 \mathrm{~cm}$. in length taken at Eten, Peru.

Head contained $4 \frac{4}{5}$ times in length without caudal; its width less than its length by nearly 2 diameters of eye, and its depth at occiput is half its length. Depth of body contained 6 times in length. Body slender, tapering but little to the wide, thin, caudal peduncle, the depth of which is contained $7 \frac{1}{3}$ times in body length. Eye equidistant from tip of snout and edge of opercle; its length $3 \frac{1}{2}$ in postorbital part of head, and 3 times in interocular space. Width of premaxillary tooth patch one-sixth of its length; that of mandible a little narrower. Lips, and a region a short distance behind lower lip, slightly papillose. Upper maxillary barbel reaching just past preopercle, but scarcely to gill opening. Nasal barbel of same length but much more slender. Spines on lower edge of preopercle unequal in size; the longest ones one-half diameter of eye.

Dorsal with 12 rays, only 7 or which are branched; the others not evident until skin is dissected away in front of branched rays. Anal with 9 rays, only 5 branched. Origin of dorsal behind middle of body a distance equal to length of dorsal base; its first ray just behind base of ventrals, and its last ray a little in front of first anal ray. Distance from base of last anal ray to base of median caudal rays equal to length of head. Upper pectoral ray produced in a fine filament slightly beyond other rays; its length equal to length of head behind posterior nasal opening. Ventrals reaching a little more than half the distance between their base and first anal ray. Caudal truncate when fin is spread, but when its rays are parallel its posterior edge is slightly concave. 
Body covered with large, nearly round, dark-brown spots, as large, or usually much larger, than long diameter of eye. On head and caudal fin they are smaller; on ventral surface just behind gill opening they are nearly faded out, but still erident. Anteriorly they are more crowded than toward the tail. Frequently two or more of them run together and form oblong spots.

15. PYGIDIUM PUNCTULATUM Cuvier and Valenciennes.

Five specimens were collected at Callao. $P$. punctulatum appears to differ from $P$. dispar in little but color. It is thickly covered with small, dark-brown spots not over half as large as in the latter species and about twice as numerous.

All of our specimens have one more branched ray in the dorsal, and the caudal peduncle scarcely so deep or compressed.

\section{r6. PYGIDIUM RIVULATUM Cuvier and Valenciennes.}

A few half-grown specimens taken at Lake Titicaca agree very well with the description published by Eigenmann. ${ }^{a}$

The dorsal rays number 12 , of which only 7 are branched and evident without dissecting. The anal has 11 rays, 6 or 7 of which are branched. The dark markings on the body have a decided purplish cast.

\section{Family ARGID E. \\ 17. ARGES SIMONSII Regan.}

There are four specimens of this species taken in the Peruvian Andes at an altitude of 7,200 feet. The label is so disintegrated that the exact locality can not be deciphered. The type locality (Huaras, Peru) is 10,700 feet in altitude.

These specimens agree very well with the original description of the species. The teeth are incisor-like and with entire edges in the front of both jaws. There are 5 or 6 teeth in the outer series on each side of the premaxillary and 4 or 5 on each side of the mandible. One specimen, a male, $75 \mathrm{~mm}$. in length, is much deeper than the others, agreeing very well in this, as in other respects, with Regan's plate. The depth is $5 \frac{1}{6}$ in the length. The others, a male of about the same length and 2 females $90 \mathrm{~mm}$. in length, have a depth of from $6 \frac{3}{4}$ to 7 in the length. There is no other essential difference between them. No spine was found in the adipose dorsal, though the skin was dissected away in this region in two specimens. There is no difference in the position of the ventrals between the sexes such as Evermann and Kendall report in Cyclopium cyclopum. 
The origin of the ventrals is directly under that of the dorsal. The tips of the ventrals reach from five-sixths to one-half of the distance from their base to the front of anal.

\section{Family ERYTHRINID无.}

\section{HOPLIAS MICROLEPIS (Günther).}

Four specimens from Guayaquil do not differ to any appreciable extent from specimens from Panama.

H. microlepis differs from $H$. malabaricus only in having a greater number of scales. This difference, though slight, appears to be very constant. Only two specimens of the latter species collected at Breves and Moraj, Tocantins River, Brazil, are at hand for comparison.

H. microlepis has 42 lateral line scales; 12 scales in a series running obliquely from base of ventral to base of dorsal; 13 series across back in front of dorsal from one lateral line to the other, not counting the pore-bearing scales or the few crowded scales in front of dorsal; 11 series counting in the same way behind dorsal; and 16 or 17 in a median line from occiput to dorsal. H. malabaricus has 38 lateral line scales; 11 series from ventral to dorsal; 11 series across back in front of dorsal; 9 behind dorsal; 14 from occiput to dorsal. There may be a constant difference in number of dorsal rays. Our two specimens of H. malabaricus have 15 dorsal rays, while $H$. microlepis has 13 or 14 , usually the latter number.

Table of measurements of Hoplias microlepis and Hoplias malabaricus.

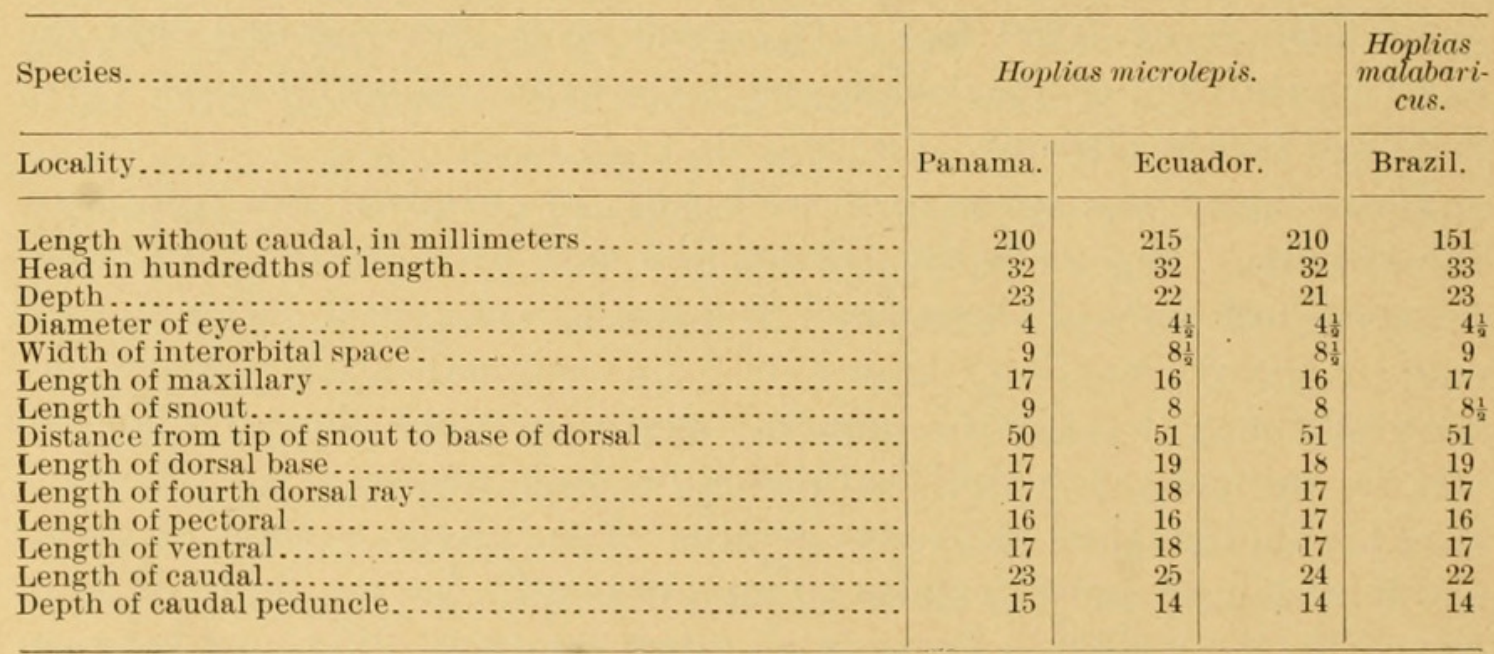

r9. LEBIASINA BIMACULATA Cuvier and Valenciennes.

Specimens taken at Callao and Eten, Peru, and at Santa Rosa, Ecuador. The following description is drawn from the Eten specimens from 15 to $18 \mathrm{~cm}$. in length:

Head, $3 \frac{4}{5}$ to 4 in length to base of caudal; depth, $3 \frac{1}{2}$ to 4 . Eye, 6 in head; snout, 4 ; interorbital space, $2 \frac{3}{4}$; longest dorsal ray, $1 \frac{5}{6}$; base 
of dorsal, 3; longest anal ray, 2; base of anal, 2; length of pectoral, $1 \frac{1}{2}$; ventral, $1 \frac{3}{4}$; upper lobe of caudal, $1 \frac{1}{4}$; depth of caudal peduncle, 2 . Dorsal, 10; anal, 11; ventral, 8. Scales, 25.

Front of head rounded in profile; fins all rounded; ventrals a little in advance of dorsal.

Color of specimens that had been a short time in formalin: Scales on dorsal part of body tinged with yellow; 3 rows of orange yellow spots, one on each scale, extending along side of body. Pectoral fin with a little orange coloring; ventral, anal, and caudal bright orange red; the color more brilliant near edges of fins. A dark lateral band ending anteriorly in a dark spot just behind opercle, and posteriorly in a darker more conspicuous spot at base of caudal; these markings more conspicuous in the young.

Some smaller specimens from Santa Rosa, Ecuador, differ in not having the small lateral spots, and in having a larger eye.

In the plate published by Cuvier and Valenciennes, ${ }^{a}$ the dorsal is truncate across the ends of the rays, leaving the corners sharp. The dorsal should be broadly rounded and without angles. The caudal lobes are too sharp, and the lower jaw projects too much.

\section{Family CHARACINID A.}

\section{CURIMATUS TROSCHELII (Günther).}

A single specimen taken in the market at Guayaquil. It agrees very well with Doctor Günther's description of the type.

\section{PROCHILODUS CAUDIFASCIATUS, new species.}

Head, $2 \frac{3}{5}$ in length to base of caudal; depth, $3 \frac{1}{2}$. Eye, between eyelids 7 in head; snout, 2 ; interorbital space, 2; third dorsal ray, $1 \frac{1}{4}$; base of dorsal, $1 \frac{5}{6}$; length of pectoral from hase of first spine, $1 \frac{2}{9}$; second anal ray, $1 \frac{3}{5}$; base of anal, $2 \frac{1}{2}$; depth of caudal peduncle, $2 \frac{1}{3}$. Dorsal, 12; anal, 10; ventral, 9 . Scales, 47.

Eye with thin membranous eyelids; its anterior edge at the middle of the length of the head; the middle of the eye a little below the level of the angle of the mouth, and vertically equidistant from the dorsal and ventral outlines of head. Cavity beneath preorbital bone, into which maxillary elements retreat, fails to reach eye by a space half the diameter of eye. Maxillary elements forming a thick rounded projection beyond the mandible. When mouth is closed, its incision is directed obliquely in a line that if continued would extend through the center of eye. Teeth thin, small, and leaf like, in a single row at the outer edge of a thick spongy tissue that deeply covers the bones of the mouth; their edges outward toward edge of mouth. Near front of mouth on each jaw a single row of similar teeth curves inward and 
backward, and, meeting its opposite fellow in a point directed down the throat, incloses a triangular area at front of mouth. The teeth of the inner row set transversely to those of the outer row. On the lower jaw the inclosed triangular area is much smaller than that in the upper jaw. Nostrils situated one diameter of eye in front of eye.

Pectoral reaching to within three-fourths of a diameter of eye of base of ventrals. Origin of dorsal midway between tip of snout and one scale behind base of adipose dorsal. Fourth dorsal ray longest, forming the point of fin; each dorsal ray with a thin lateral dermal flap extending nearly its whole length. Adipose dorsal inserted midway between base of dorsal and tips of median caudal rays; its base very short; its tip extending twice its height beyond its base posteriorly. Second anal ray the longest, 3 times the length of the last ray; posterior edge of anal somewhat lunate. Length of ventral equal to that of pectoral; its tip reaching a little more than two-thirds of the distance from base of its first ray to front of anal.

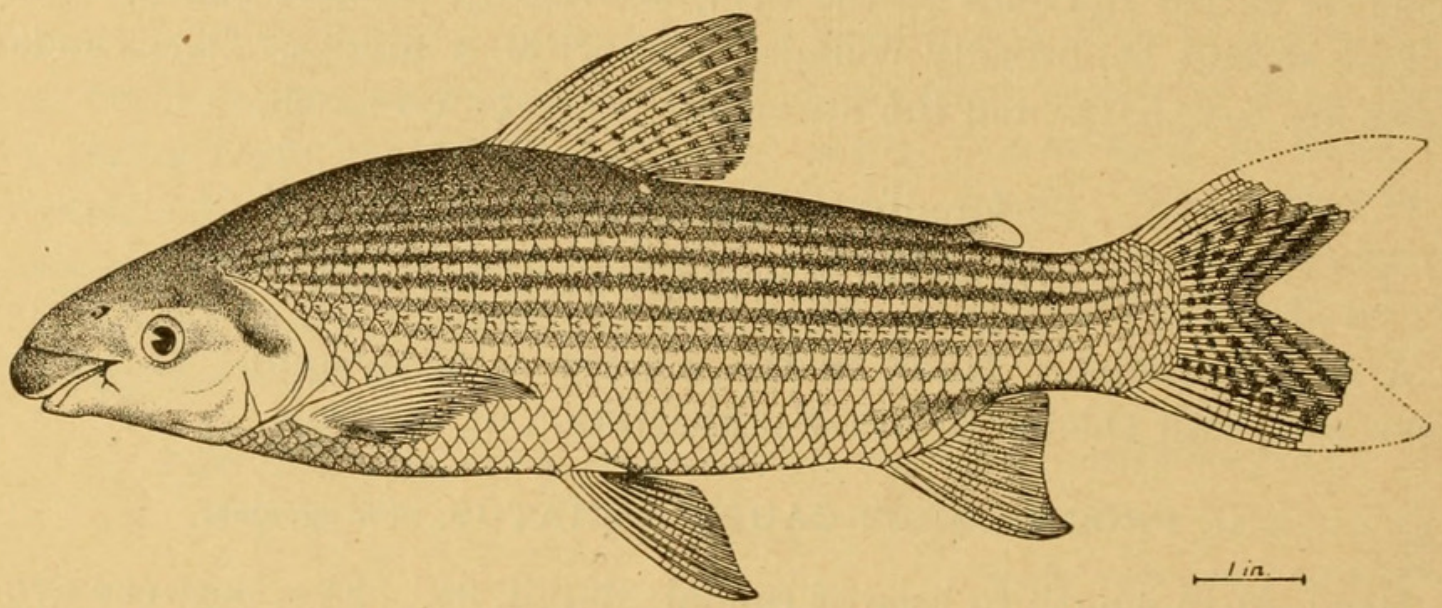

Fig. 5.-Prochilodus caudifasciatus.

Surface of scales finely granular; 15 in a median row from front of dorsal to occiput; $8 \frac{1}{2}$ in an oblique row from front of dorsal to lateral line; $6 \frac{1}{2}$ from front of anal to lateral line.

Sides with alternate dark and silvery stripes following the rows of scales. Lateral line occupies a silvery stripe below which there are about 4 dark stripes fading into the silvery of the belly; about 5 dark stripes show above lateral line, and others are lost in dark color of back. Head dark to lower part of eye, silvery on sides below eye, and white on ventral surface. Maxillary elements dark; narrowly bordered with white on lip. Dorsal with spots on the rays, which form about 8 broken cross streaks. Caudal with several rather narrow dark cross streaks which posteriorly follow the edge of the forked caudal, but become more nearly vertical anteriorly; toward each edge of caudal some of the streaks fork and shorter streaks are introduced. No longituaiinal median streak present on caudal. Anal very slightly tinged with dusky; ventral and vestoral colorless. 
This species may be known by the elongate form, in connection with the number of scales, the length of head, and the bars on caudal. The species having the caudal barred are all deeper.

The type and only specimen is $32 \mathrm{~cm}$. in entire length and was taken in the Rio Perené at Perené, Peru. It is deposited in the U. S. National Museum, Cat. No. 53473.

\section{LEPORINUS LESCHENAULTI Cuvier and Valenciennes.}

Two specimens collected at the market at Guayaquil. These unlike the specimens described by Doctor Günther ${ }^{a}$ agree very well in length of head and depth of body with the figure published by Cuvier and Valenciennes. They have 39 or 40 scales in the lateral line; the type is said to have 36 .

\section{TETRAgONOPTERUS PERUANUS Muller and Troschel.}

Specimens were taken from Rio de Eten, at Eten, and at Payta, Peru.

Head, 4 to $4 \frac{1}{5}$ in length to base of caudal; depth, $2 \frac{1}{2}$ to $2 \frac{3}{4}$; eye, $3 \frac{1}{2}$ in head; interorbital space, $2 \frac{1}{2}$ to $2 \frac{3}{4}$; snout, $3 \frac{1}{2}$ to $3 \frac{3}{4}$; maxillary, $2 \frac{1}{2}$; height of front of dorsal, 1 to $1 \frac{1}{4}$; front of anal, $1 \frac{1}{2}$ to $1 \frac{2}{3}$; pectoral, $1 \frac{1}{5}$ to $1 \frac{1}{3}$; ventral, $1 \frac{1}{2}$; caudal, $\frac{4}{5}$ to 1 . Dorsal, 10 or 11 ; anal, 28 to 30 ; scales, 36 to 39 ; transverse series, $7+1+7$.

Ventral outline of body forming a deeper curve than dorsal outline. Nape straight or sometimes very slightly concave. Maxillary extending past front of eye nearly to front of pupil. Gill rakers short and rather slender; the longest one-third of diameter of eye; 10 or 11 on lower limb of arch.

Front of dorsal midway between base of caudal and tip of snout, or varying from this point to a point midway between base of caudal and anterior margin of eye. Origin of anal under base of sixth or seventh dorsal ray. Ventrals placed considerably in front of dorsal; their tips not reaching to front of anal. Pectoral scarcely reaching to base of ventral.

A dark lateral band runs from upper part of gill opening to base of middle caudal rays, becoming broad behind middle of body, constricted on caudal peduncle, again expanding to a large dark spot at base of caudal, and continued to tips of median caudal rays. Anteriorly an indefinite spot, slightly lighter than the ground color, more or less completely separates a small portion of the lateral band from the main part. Specimens from Eten do not have the lateral band so much expanded just behind middle of body and not so dark or conspicuous anteriorly as those from Payta. 


\section{TETRAGONOPTERUS FEST $Æ$ Boulenger.}

A dozen specimens collected at Mirador, Ecuador, the longest the same length as Boulenger's type, $65 \mathrm{~mm}$. These differ from the original description in having a smaller eye as compared with the snout and head, a smaller average number of scales, and the lateral spots always conspicuous. Mr. C. Tate Regan has kindly compared one of these specimens with the typical specimens in the British Museum and has pronounced them to be identical.

Head, 4 to $4 \frac{1}{2}$ in length to base of caudal; depth, $2 \frac{1}{2}$ to 3 . Eye, 3 to $3 \frac{1}{5}$ in head; snout, 4 to $4 \frac{1}{4}$; height of dorsal 1 ; height of front of anal, $1 \frac{1}{3}$; pectoral, $1 \frac{1}{6}$. Dorsal, 10 or 11 ; anal, 34 or 35 . Scales, 41 to 44 ; 8 series above lateral line and 8 or 9 below.

Body compressed and rather deep, somewhat angulated in front of dorsal; ventral outline forming a more even curve than that of dorsal; only the larger specimens concave at nape. Breast transversely rounded in front of ventrals. Snout blunt; jaws equal, or the lower a little shorter. Teeth rather large, 4 on each side of lower jaw. Maxillary smooth on its anterior edge; scarcely reaching to anterior border of eye, but extending down nearly to opposite lower border or eye. Gill rakers slender; the longest one-third of eye; 10 to 12 on lower part of arch.

Origin of dorsal midway between base of caudal and anterior border of eye. Tip of dorsal when depressed reaching to a point midway between base of last dorsal ray and base of auxilliary caudal rays. Front of anal under middle of dorsal; last anal ray extending a little past adipose dorsal. Posterior outline of anal shallowly concave. Pectoral reaching past base of ventral a distance equal to three-fourths diameter of eye. Ventrals barely reaching front of anal.

Color dusky above, darker on top of head, sides and lower parts pale. A dark lateral band running from upper part of gill opening to base of median caudal rays, where it terminates in an expanded darker blotch, with sometimes a second, smaller, less conspicuous, blotch behind it on base of median caudal rays. The lateral band grows darker posteriorly and is bordered below by a very fine dark line. Traces remain of a narrow silvery lateral band directly below the dark band, Crossing the lateral band anteriorly are 2 large, conspicuous, elliptical, or sometimes crescent-shaped spots, extending obliquely downward and forward; the posterior one above the tip of the pectoral, the other a little posterior to the base of the pectoral. A few pigment dots on posterior parts of dorsal, anal, and caudal; fins otherwise colorless.

In the original description the eye is said to be twice the length of the snout, and contained $2 \frac{1}{2}$ to $2 \frac{2}{3}$ times in the head. The scales in the lateral line number from 44 to 47 . The color as follows: Une 
bande argentée le long du corps, se terminant en une tache noire sur la queue, à la base de la caudale; en avant, sur la ligne latérale, deux taches noires plus ou moins nettes; ces taches manquent parfois.

\section{TETRAGONOPTERUS RUTILUS Jenyns.}

A single specimen, $165 \mathrm{~mm}$. in length, collected in the Rio Perené, on the east slope of the Andes in Peru, appears to be referable to this species. It differs from $T$. peruanus in having the dorsal more anteriorly placed. The front of the dorsal is midway between the tip of the snout and a distance behind the tip of the adipose dorsal equal to a diameter of the pupil. The anal is one diameter of the eye behind the base of the last dorsal ray, or nearly under the tip of the last dorsal ray. The ventrals are two-thirds of a diameter of the eye in front of the dorsal.

\section{BRYCON ATRICAUDATUS Kner.}

Several specimens were taken at Payta and one at Eten, Peru. The longest $15 \mathrm{~cm}$. in length.

Head, $3 \frac{1}{2}$ in length without caudal; depth $3 \frac{1}{4}$. Eye, $4 \frac{1}{2}$ in head; maxillary, $2 \frac{1}{4}$; snout, $3 \frac{3}{5}$; interorbital space, 4 . Dorsal, 10 or 11 ; anal, 28 or 29 . Scales, 54 to 56 ; transverse series, $10+1+6$.

Lower jaw included; maxillary reaching to below middle of eye. Gill rakers slender, the longest two-fifths of diameter of eye; 15 on lower limb of arch. Origin of dorsal midway between nostril and base of caudal; one diameter of eye behind base of ventrals. Anal one-half of diameter of eye behind base of dorsal. Pectoral not quite reaching to base of ventral, which does not reach to front of anal. Caudal deeply forked.

A dark, usually very definite humeral spot crosses the anterior end of lateral line, the greater part of its area above the line. An inconspicuous blotch at base of caudal.

\section{Family STERNOPYGID\&.}

\section{STERNOPYGUS ÆQUILABIATUS (Humboldt).}

Several specimens collected at Guayaquil, the largest $53 \mathrm{~cm}$. in length.

Depth of body, five-sixths to seven-eighths of length of head to upper end of gill opening. Snout, contained 3 times in head; maxillary, 4 to $4 \frac{1}{2}$ times. Eye (between adipose eyelids), $5 \frac{1}{2}$ to 6 times in snout, 16 to 18 in length of head. Length of gill opening less than length of snout by 1 diameter of eye. Fine movable teeth with their tips only slightly projecting beyond the spongy dermal tissue are set in broad bands on jaws; the upper band nearly straight and broadly rounded at its ends; one-third as broad as long; the lower band crescent- 
VOL $\mathrm{xxx}$.

shaped, tapering to a point at its ends, and a little longer than upper band, though scarcely so broad.

Head and body dark with small, round punctulations. A pale band beginning at a point midway between base of anal fin and lateral line, a little anterior to middle of body, follows the ventral outline of body to tip of tail; posteriorly it curves up and runs along the lower edge of lateral line.

\section{Family OPHICHTHYID A.}

28. OPHICHTHUS CALLAENSIS (Günther).

A specimen from Guayaquil is probably referable to this species though differing somewhat from the original description. The gape is contained $2 \frac{1}{2}$ times in the head; the head is less than balf the length of the trunk; and the tail is $1 \frac{3}{4}$ times the rest of the body.

The type is described as having the gape one-third the length of the head; the head more than half the length of the trunk; and the tail $1 \frac{1}{2}$ times the rest of the body.

Jordan and Davis ${ }^{a}$ report on specimens having the head as compared with the trunk similar to the specimen at hand.

\section{Family ELOPID A.}

29. ELOPS SAURUS (Linnæus).

Our specimen from Guayaquil.

\section{Family CLUPEID A.}

3o. POTAMALOSA NOTACANTHOIDES (Steindachner).

Specimens taken at Callao, Peru.

3I. SARDINELLA FIMBRIATA (Kner and Steindachner).

Specimens from Callao, Peru, agree very well with the original description. The dorsal is slightly in front of the middle of the length of the body to the base of the caudal; and the pectoral is from $1 \frac{2}{3}$ to $1 \frac{3}{4}$ times in the head, not 2 times as originally described.

\section{ILISHA FURTHI (Steindachner).}

Four specimens collected at Guayaquil, Ecuador, from 22 to $24 \mathrm{~cm}$. in length. These do not differ from specimens from Panama except that the depth is contained 3 times in the length to base of caudal. Panama specimens of this length are deeper, while those of this depth are larger. 
Family POECILIID A.

33. ORESTIAS PENTLANDI Valenciennes.

This species is the best represented of its genus in the collection. Sixteen specimens, from 18 to $20 \mathrm{~cm}$. in length, were collected at Lake Titicaca.

$O$. pentlandi is an elongate form like $O$. cuvieri, but may be known at sight by the short head, the small mouth and eye, the more complete and smoother squamation of the anterior part of the body, and the slender caudal peduncle. The form of the head and body is more symmetrical than in any Orestias here represented. The back is not elevated to a blunt ridge; the temporal region is not laterally produced, and the anterior dorsal outline forms an unbroken curve to the tip of the snout.

Head $3 \frac{4}{5}$ to $4 \frac{1}{5}$ in length to base of caudal. Gape of mouth from symphysis of premaxillaries to lower angle of mouth equal to diameter of eye; width of mouth between lower angles $1 \frac{1}{2}$ to $1 \frac{1}{3}$ times the diameter of eye. Interorbital space evenly arched; 2 to $2 \frac{1}{4}$ times the diameter of eye.

Series of seales above middle of sides from 55 to $60 ; 16$ or 17 rows between front of anal and front of dorsal. Side scaled to a level with lower pectoral ray or a little below. Area in front of pectoral usually naked, but sometimes with a few scales. Top of head back to behind eyes naked in some specimens, entirely scaled to slightly in front of eyes in others, or with a few scattered scales in still others. A narrow suborbital region always naked; scales of cheek extending forward in varying degrees.

Caudal peduncle narrow and less compressed than in any other Orestias in the collection, though there is a large individual variation in this respect. Width of caudal peduncle from 2 to 3 times in length of head.

\section{ORESTIAS CUVIERI Valencienne}

Four specimens from 22 to $24 \mathrm{~cm}$. in length from Lake Titicaca.

This species has a larger more oblique mouth, larger teeth, and a longer head in proportion to the depth of the head, than any other species of Orestias here considered.

Depth of head at occiput $1 \frac{4}{5}$ to 2 in length of head. Length of gape from symphysis of premaxillaries to lower angle of mouth $\frac{1}{3}$ to $\frac{1}{2}$ times greater than diameter of eye, and equal to width of mouth across its lower angles. Eye contained $1 \frac{1}{3}$ to $1 \frac{1}{2}$ times in distance from its anterior edge to mouth, or 2 times obliquely across top of snout to union of premaxillaries, and $1_{5}^{4}$ times in interorbital space.

Ventral surface naked below a line extending obliquely downward and backward from upper angle of gill opening to base of last anal ray, or sometimes to lower caudal rays, leaving a narrow naked area 
on lower side of caudal peduncle. A more or less continuous row of scales runs along the medium line of back, on each side of which is a naked area with or without scales scattered sparsely over it. Naked area may be continued over top of head, interrupted only by a few scales at occipital region, or top of head may be wholly covered with rough seales to opposite front of eyes. Side of head wholly naked except where scales irregularly cover upper half of opercle and small area on cheek behind eye. Region in front of pectoral naked.

\section{ORESTIAS AGASSIZII Valenciennes.}

Four specimens, from 150 to $165 \mathrm{~mm}$. in length, were collected in Lake Titicaca at Chililaya, Bolivia.

This species, in proportions of body, stands about midway between the elongate $O$. pentlandi and $O$. cuvieri and the short $O$. albus and $O$. luteus.

I have little to add to the description published by Garman. ${ }^{a}$ Mouth very small; gape from symphysis of premaxillaries to lower angle of mouth equal to long diameter of orbit; width of snout between lower angles of mouth from $1 \frac{1}{3}$ to $1 \frac{1}{2}$ times diameter of orbit. The picture published by Cuvier and Valenciennes shows an area in front of pectoral covered with scales. In three of our four specimens this area is entirely naked; in the other 2 or 3 scales remain and depressions indicate the former presence of other scales. It is probable that these scales are lost in the adult fish, as are those on top of snout. The head is contained 4 times in the length to base of caudal, not $4 \frac{1}{4}$ as in Garman's specimens.

\section{ORESTIAS ALBUS Valenciennes.}

Six specimens from 148 to $155 \mathrm{~mm}$. in length collected in Lake Titicaca.

This species (at least of the size at hand) may be at once known by the naked area on the upper part of the side, in connection with the short body.

Length of head, without projecting mandible, $2 \frac{1}{2}$ to $2 \frac{3}{4}$ in length to base of caudal. Depth of head at occiput $1 \frac{1}{2}$ in length of head, and equal to width of head at opercles, or sometimes a very little less than width of head. Diameter of eye equal to its distance from mouth; $1 \frac{1}{3}$ in snout measured obliquely over top of snout to union of premaxillaries; contained $1 \frac{3}{4}$ to $1 \frac{4}{5}$ times in interorbital space.

Mouth vertical; lower end of gape below level of eye. A considerable amount of variation is exhibited in the squamation. Usually there is a continuous single row of rough plates from the occiput to the dorsal, with a large naked area at each side of it. In some specimens, however, the dorsal plates are absent anteriorly and the lateral 
naked areas are not separated from each other in this region. In one or two examples a few scales or plates are irregularly scattered over the lateral naked areas. Usually the naked areas extend back nearly to opposite front of dorsal, but in some cases it does not extend more than half that distance, and in others it is continued back along the whole base of dorsal. Uusually the side is scaled to a level of the lower pectoral ray, but sometimes the scales are absent below a line curved downward between the base of the upper pectoral ray and the front of anal. A triangular area of scales on cheek sometimes reaches forward to below front of eye and sometimes ceases below middle of eye; in either case the preorbital region may be entirely naked or with a few scattered plates. A few of the specimens show traces of scattered plates on the ventral surface, probably indicating their presence on smaller specimens. The region in front of pectoral is naked and nearly covered by the opercle.

\section{ORESTIAS LUTEUS Valenciennes.}

This species is represented by 6 specimens, from 122 to $142 \mathrm{~mm}$. in length, taken in Lake Titicaca at Chililaya, Bolivia. It is at once known by the wide short head, having strong lateral angles.

$O$. luteus has a much shorter head than O. albus; head 3 to $3 \frac{1}{4}$ times in length of body to base of caudal. The height of head is greater, though contained about the same number of times in the shorter head. Width of head nearly equal to length of head. The back is much more elevated than in $O$. albus, and there is a strong concave region at each side of back. The elevation of back makes the dorsal outline of head and nape more or less concave. Head as viewed from above much produced laterally at the temporal region, forming broadly rounded angles which taper quickly to the narrow scarcely produced snout. Mouth smaller than in O. albus; not quite vertical; lower end of gape scarcely extending below lower margin of eye. Scales more regularly placed and no naked area present on side of back; scales covering side more completely below; naked area of belly not reaching to level of lower pectoral ray. Opercle not extending so far over region in front of pectoral, which region is nearly always thickly covered with rough scales, though in one specimen it is naked.

\section{Family TYLOSURIDÆ.}

38. TYLOSURUS JORDANI, new species.

Head, $2 \frac{3}{4}$ in length from tip of upper jaw to base of caudal. Depth at occiput, twice diameter of eye. Eye, $3 \frac{1}{4}$ in postorbital part of head; interorbital space, $2 \frac{4}{5}$ in same space. Eye and postorbital part of head contained $1 \frac{5}{6}$ times in mandible, measuring from eye. Dorsal, 13; anal. 14. Scales, 240 . 
Body as broad as deep; caudal peduncle very slightly compressed, but appearing perfectly round; no caudal keel. Interorbital space slightly wider than eye, and flatter than in T. scapularis. The longitudinal channel little evident, and behind eye scarcely sunk below general level of top of head. In the latter species (two specimens from Panama) the top of head bears a deep groove which extends back nearly to opposite middle of cheek, where it terminates rather abruptly. Scales on cheek much smaller than in $T$. scapularis as shown in accompanying figures; in 21 or 22 irregular rows counting longitudinally, and appearing scarcely more than half as large as in the latter species, which has about 15 irregular rows on cheek.

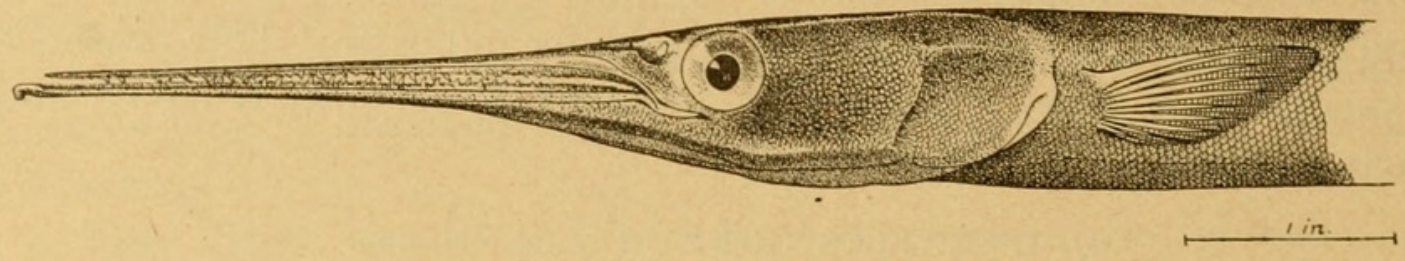

FIG. 6.-TYLOSURUS JORDANI.

Pectoral contained $1 \frac{1}{4}$ ir. postorbital part of head. Ventrals inserted one diameter of eye nearer base of caudal than posterior margin of eye. Front of dorsal over base of fifth anal ray; tip of last anal ray reaching to below base of next to last dor:al ray. Caudal slightly lunate; the lobes rounded; lower lobe considerably longer than upper.

Color as in $T$. scapularis, but everywhere darker. Under parts little lighter than sides and back. Fins all dusky; a dark scapular spot present. No trace remains of a silvery lateral band, but occupying the same region is a dark bluish band that is very indefinite. The specimen was preserved in formalin and if it had any silvery color it was destroyed.

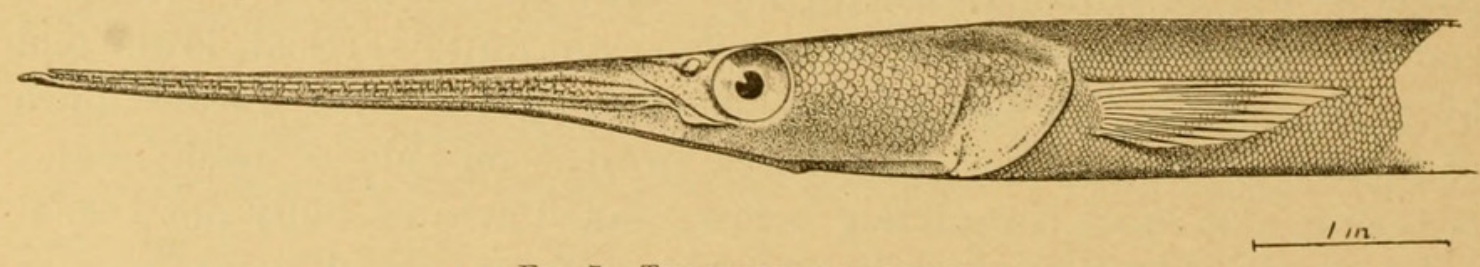

Fig. 7.-TylosURUS SCAPUlaris.

This species is close to T. scapularis Jordan and Gilbert, but differs in having smaller scales, particularly those on cheek, and scarcely any interorbital groove. From T. fuviatilis (Regan) it differs in having fewer fin rays, more posterior insertion of the ventrals, and the interorbital space greater than the length of the eye. T. Aluviatilis has 15 or 16 dorsal rays and 17 or 18 anal rays.

The type and sole specimen is $37 \mathrm{~cm}$. in length and was collected at Guayaquil, Ecuador. It is deposited in the U. S. National Museum, Cat. No. 53469.

I take pleasure in naming this species for Dr. David Starr Jordan. whose advice first made my study of ichthyology feasible. 
Family SYNGNATHIDA:

39. SYNGNATHUS STARKSI (Jordan and Culver).

A specimen from the river at Santa Rosa, Ecuador, differs from the typical specimens only in having the snout strongly curved up and the dorsal situated about half a body ring more posteriorly. The number of rings and fin rays are the same.

\section{Family ATHERINID A:}

40. KIRTLANDIA PACHYLEPIS (Gunther).

A single small specimen from Guayaquil, Ecuador.

\section{I. BASILICHTHYS REGILLUS Abbott.}

Several specimens collected at Callao, the type locality of the spe cies. They agree in all essential respects with the typical specimen, with which they have been compared. In the original description the statement "origin of first dorsal nearer snout than base of caudal by one-third length of head," should read, nearer base of caudal than snout by one-third length of head.

$$
\text { Family MUGILID A: }
$$

42. MUGIL CUREMA Cuvier and Valenciennes.

Two specimens taken at Guayaquil, Ecuador.

43. MUGIL HOSPES Jordan and Culver.

A specimen from Guayaquil, Ecuador, agrees in all characters with specimens from Panama, and with the typical specimens from Mazatlan. Like them it has in the mouth the parasitic crustacean.

$$
\text { Family POLYNEMID,E. }
$$

\section{POLYDACTYLUS APPROXIMANS (Lay and Bennett).}

One moderate-sized specimen from Guayaquil. It and a specimen from Callao, Peru, that is in the Stanford University collections, have 15 anal rays rather than 13 or 14 , as in all of the specimens examined from Panama and Mexico. It is much darker than the northern specimens, but differs in no other respect.

\section{Family SCOMBRID A.}

45. SCOMBER JAPONICUS Houttuyn.

Specimens from Callao, Peru. 


\section{SARDA CHILENSIS (Cuvier and Valenciennes).}

One specimen from Callao, Peru.

\section{Family CARANGID E.}

\section{OLIGOPLITES MUNDUS Jordan and Starks.}

Two specimens collected at Guayaquil. One of them has but 16 anal rays, though in other respects it differs in no way from specimens from Panama and Mexico. The usual number of anal rays is 19 or 20; one specimen from Panama has 18.

Mr. C. Tate Regan, comparing specimens of O. saliens with a specimen of $O$. mundus, reports them to be identical. His specimen of $O$. mundus can not be correctly identified, as these two species differ greatly. The maxillary of $O$. mundus is 17 or 18 hundredths of the length without caudal. In Bloch's figure of the type of $O$. saliens the maxillary is only 12 hundredths, and a specimen of what is apparently O. saliens from Brazil, in the Stanford University collections, has a maxillary 14 hundredths. $O$. mundus has the head from 25 to $26 \frac{1}{2}$ hundredths of the length, and the depth from 34 to 36 hundredths. Bloch's figure shows $O$. saliens to have the head 22 and the depth 29 hundredths, which agrees exactly with our Brazilian specimen of that species.

Mr. Regan's Pacific specimen may be $O$. altus Günther, as apparently that species is very close to, if not identical with, O. saliens.

48. NEPTOMENUS CRASSUS, new species.

Head, 3 to $3 \frac{1}{4}$ in length to base of caudal ( $3 \frac{3}{4}$ to 4 including caudal); depth, $3 \frac{1}{2}\left(4 \frac{1}{3}\right)$. Eye, 5 to $5 \frac{1}{4}$ in head; snout, $3 \frac{4}{5}$ to 4 ; maxillary, $3 \frac{1}{2}$; interorbital space, 3 to $3 \frac{1}{5}$. Dorsal, VII, I, 27; anal, II, 21; scales, 90 above lateral line; 97 inlateral line.

Ventral outline of body more deeply curved than dorsal; head rather wide and blunt. Snout as viewed from above wide and broadly rounded in front; its width in front of eyes a little greater than its length. Jaws equal; mouth rather oblique. Anterior end of maxillary slightly below a level with middle of eye; posterior end reaching to below front of eye or very slightly past. Maxillary not protractile; the skin continuous from upper lip to top of snout. Teeth very fine, in a single even row on jaws; the lower row shutting inside of the upper "like a box-lid," as described for the related genus Cubiceps. No teeth on vomer or palatines. Interorbital space broad and evenly convex. Top of head and snout of a rubber-like consistency and thickly set with small pores. Eye considerably above the middle of the height of the head (nearly in the middle in $N$. brama); a line drawn through the middle of the head longitudinally passes slightly 
above the lower edge of the eye. Narrowest part of preorbital including eyelid one-half of diameter of pupil; the bone only one-fourth of pupil. Posterior edge of preopercle concave; the lower edge and the angle broadly rounded. Gill rakers moderately slender; the longest scarcely one-half the diameter of eye; 15 of them on lower part of arch.

Scales cycloid and regularly arranged; those of lateral line scarcely enlarged but raised to a slight ridge, especially on caudal peduncle. Thin scales present or cheeks and opercles; the rest of head naked.

Spinous dorsal low; closing into a groove; the longest spine not exceeding diameter of eye in length. Soft dorsal and anal highest in front; the longest rays equal to length of snout. Anal spines very small and not separated from the soft rays; the first spine directly under middle of soft dorsal. Soft dorsal and anal coterminous; the distance from base of dorsal to upper caudal rays $1 \frac{3}{4}$ times the diameter of eye. Pectoral reaching to above front of anal; its length a little

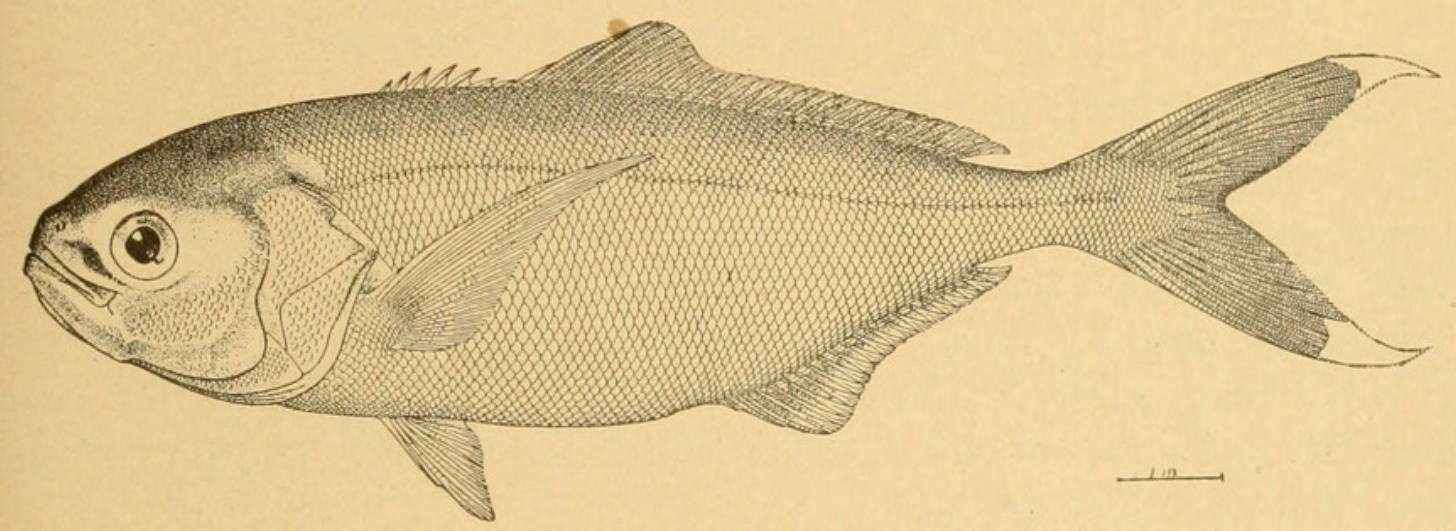

Fig. 8.-Neptomenus CRAsSUs.

less than that of head. Ventrals adnate to the belly; their tips reaching halfway from their base to the middle of vent. Caudal deeply forked.

Color, dusky above; black on top of head; sides and lower parts silvery. Sides of head, and particularly mandible, set with small points of dark brown. Vertical fins dusky; the dorsals darker than anal; pectoral slightly dusky; darker on inner surface; axil dark brown.

This species agrees with $N$. brama in number of fin rays and scales, but if current descriptions of the latter are dependable it is a more slender species, with a larger head, and with the eye above the middle of the height of the head.

Günther describes the type as having the depth $3 \frac{1}{4}$ in the total length, and the head $4 \frac{1}{2}$. He evidently includes the caudal in his measurements, as his specimen was $14 \frac{3}{4}$ inches in total length and $4 \frac{1}{2}$ inches deep.

The type, however, was a stuffed specimen, and these measurements could not be depended upon did not a description by Hutton (presumably from fresh or alcoholic specimens) agree very well on these points

Proc. N. M. vol. $\mathrm{xxx}-06-50$ 
with the description of the type: Depth, $2 \frac{3}{4}$ in length, without caudal; head, $3 \frac{3}{4}$.

This is apparently the first record of the occurrence of this genus outside of Australian seas.

Two specimens of about the same length were taken at Callao, Peru. The type is $34 \mathrm{~cm}$. in length, and is deposited in the U. S. National Museum, Cat. No. 53465. The cotype is in Stanford University museum.

\section{CARANX HIPPOS (Linnæus)}

A specimen from Guayaquil.

50. VOMER SETIPINNIS (Mitchill).

One specimen from Callao.

5I. SELENE VOMER (Linnæus).

Two specimens from Guayaquil.

\section{TRACHINOTUS KENNEDYI Steindachner.}

Two specimens from Guayaquil differ from specimens from Panama only in color. The body is black above and dark on sides with small punctulations. The lobe of the dorsal is black and the other fins are very dark, except the ventrals, which are dusky. The maxillary and side of the head are dark. Panama specimens are bright silvery, and slightly dusky above. The dorsal is dusky and the other fins very slightly dusky except the ventrals, which are white. The side of the head and maxillary are silvery.

\section{TRACHINOTUS PALOMA Jordan and Starks.}

A specimen from Callao, $267 \mathrm{~mm}$. in length without caudal, has a smaller eye ( $6 \frac{1}{2}$ in head) than a specimen from Panama, but is not otherwise essentially different.

In comparing this species with T. carolina, specimens of nearly the same size should be selected. In the original description of this species the head was alleged to be larger than in $T$. carolina. Gilbert and Starks in comparing specimens of about the same size found no difference in this respect, though the species was found to be well distinguished by other characters. ${ }^{a}$ In comparing the specimen at hand with a large specimen of $T$. carolina, $345 \mathrm{~mm}$. in length without caudal, the head is shorter, being $4 \frac{1}{6}$ in length in $T$. paloma, and $3 \frac{2}{3}$ in $T$. carolina.

\section{Family CENTROPOMID A. \\ 54. OXYLABRAX ARMATUS (Gill).}

Three small specimens from Guayaquil. 


\section{Family SERRANID E.}

55. PARALABRAX HUMERALIS (Cuvier and Valenciennes).

Numerous specimens were collected at Callao, Peru, from 10 to 35 cm. in length. The young of $10 \mathrm{or} 12 \mathrm{~cm}$. in length have 7 cross bars, composed of small dark-brown spots scattered over a dusky ground color. These are regular in form and position on lower half of sides, but on middle of sides a longitudinal band more or less interrupts them, and their upper ends are more indefinite and do not always coincide in position with their lower ends. A dusky band runs downward from eye obliquely across cheek. The soft dorsal, anal, and caudal have round brown spots scattered over them. On specimens $15 \mathrm{~cm}$. in length all of these markings are indistinct, and on large specimens they are altogether lost. A white spot is usually present on the back, between the lateral line and base of dorsal, opposite the notch between dorsals, both in young and adult examples.

56. PARALABRAX CALLAENSIS, new species.

Plate LXV, fig. 2.

Head, $2 \frac{1}{2}$ in length to base of caudal; depth, $3 \frac{1}{3}$. Eye, $5 \frac{3}{4}$ in head; maxillary, $2 \frac{2}{5}$; snout, $3 \frac{2}{3}$; interorbital space (bone), $5 \frac{3}{4}$. Dorsal, X, 14; anal, III, 7. Scales in 84 series above lateral line; pores in lateral line, $67 ; 15$ scales in a series running downward and backward from front of dorsal to lateral line; 34 in a series running upward and backward from front of anal to lateral line.

Lower jaw strongly projecting. Some of the teeth in jaws slightly enlarged and recurved, but not canine-like. Maxillary reaching a little past middle of eye, scarcely to posterior edge of pupil. Widest part of maxillary three-fifths of diameter of eye. Edge of preopercle closeset with small, sharp, even, spinules scarcely enlarged at the angle. The bony part of interorbital space flat. Gill rakers slender, the longest three-fifths of diameter of eye; $12+21$ in number. Top of head bearing scales anteriorly to nostrils. Snout, preorbital, maxillary, and mandible naked.

Third dorsal spine longest; from its tip to tip of seventh spine the outline of fin is somewhat concave. The first spine is half the length of the second, and the second is contained $2 \frac{1}{4}$ times in the third; the third spine is half the length of head; the last 3 spines subequal in length and contained 4 times in head. Pectoral broad, truncate at tip, and broadly rounded below; its length $1 \frac{3}{4}$ in head; reaching past tips of ventrals, but not to vent. Second and third anal spines subequal in length; the third reaching a little past tip of second when fin is reclined. Anal rays much higher than those of soft dorsal; tips of 
last rays not reaching so far back as those of soft dorsal. Caudal fin shallowly lunate.

Back and sides with wavy dark brown spots nearly as wide as pupil, running irregularly horizontal or sometimes slightly oblique. These are but little broken up on sides, but on base of caudal and on back below anterior part of spinous dorsal they break up into round spots separated by narrow interspaces. Lower part of head with stripes similar to those on body, but clearer cut at the edges. Lateral line running in a light streak much broken up by the wavy streaks crossing it. A white spot on back between lateral line and base of dorsal opposite the dorsal notch as in Paralabrax humeralis and Paralabrax albomaculatus. Upper parts of head dark brown; a few indistinct small round lighter spots on snout and preorbital region. Lower parts of head and body dusky. Spinous dorsal slightly dusky; a dark bar behind third spine, and a fainter one behind fourth. Soft dorsal mottled with dark brown. Anal and ventrals dusky, darker toward tips of rays. A dark spot in front of base of pectoral, separated from a crescentric bar of dark brown on base of pectoral rays by a narrow light bar.

The general pattern of coloration resembles very much that of Mycteroperca boulengeri, and serves at once to distinguish this species from others of its genus.

The type and sole specimen is $247 \mathrm{~mm}$. in entire length, and was taken at Callao, Peru. It is deposited in the U. S. National Museum, Cat. No. 53471.

\section{Family LUTIA NID E.}

\section{LUTIANUS ARGENTIVENTRIS (Peters).}

Three specimens from Guayaquil, Ecuador.

Family HAMULIDA.

\section{ANISOTREMUS PACIFICI (Günther).}

One specimen from Guayaquil, Ecuador, does not differ from specimens from Panama.

\section{ANISOTREMUS SCAPULARIS (Tschudi).}

Three small specimens taken at Callao, Peru. A specimen $40 \mathrm{~cm}$. in length, in the Stanford University collections, retains the black axillary spot and the spots at the last dorsal and anal rays. The preopercle is no less sharply denticulated than in small specimens. Specimens from the Galapagos Islands and Cocos Island are darker in color, and have lost the posterior dorsal and anal spots. 
6o. ISACIA CONCEPTIONIS Cuvier and Valenciennes.

Two specimens from Callao, Peru, in length 233 and $290 \mathrm{~mm}$. respectively. The head is contained in entire length to base of caudal $3 \frac{1}{3}$ times. The eye in head $5 \frac{1}{4}$ to $5 \frac{1}{2}$ times. The vertical limb of the preopercle is straight, or but little concave. The mandible is a little thicker toward the tip than in $I$. venusta, and projects slightly more. This character is somewhat more marked in the larger specimens (here drawn) than in the other. The specimens at hand are everywhere darker than in $I$. venusta, being black above and very dark on sides.

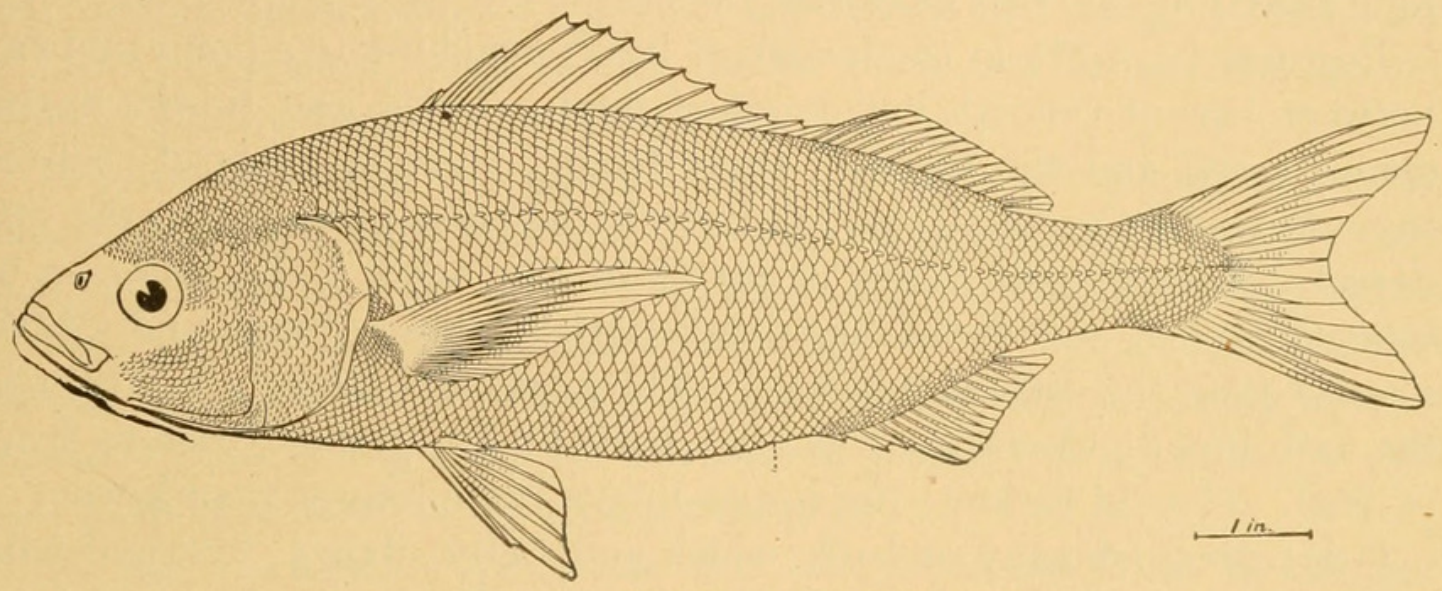

Fig. 9.-Isacia CONCEPTIONIS.

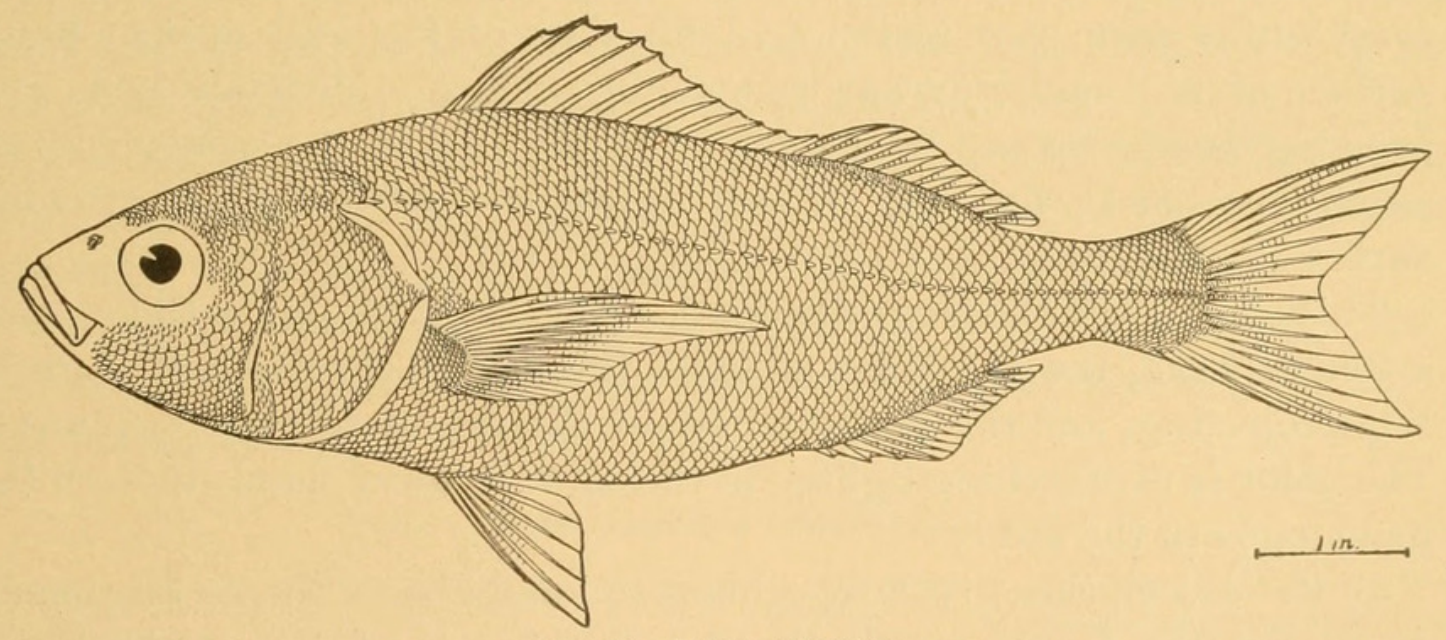

Fig, 10.-Isacia venusta.

6I. ISACIA VENUSTA, new species.

Isacia conceptionis Аввотт, Proc. Acad. of Sci. Phil., 1899, p. 350, Callao, Peru.

Head, $2 \frac{7}{8}$ to $3 \frac{1}{10}$ in length to base of caudal; depth $3 \frac{1}{4}$ to $3 \frac{1}{2}$. Eye, $4 \frac{1}{4}$ to $4 \frac{1}{2}$ in head; interorbital space, $3 \frac{3}{5}$ to 4 ; snout, $3 \frac{3}{5}$ to 4 ; maxillary, $3 \frac{3}{5}$ to 4 . DorsaI, XIII, 13 or 14 ; anal, III, 13 . Scales, 52 to 54.

Profile of head and body with the curves moderate and unbroken; the ventral and dorsal outlines similar. Jaws equal, or the lower very slightly projecting when mouth is closed. Maxillary scarcely reaching to below front of eye. Teeth in rather broad villiform bands, 
which grow narrower on sides of jaws; the outer row of teeth a little enlarged; no teeth on vomer or palatines. Interorbital space evenly curved from eyesand unbroken by ridges. Vertical limb of preopercle concave; the edges with small weak spines partly hidden by the skin, and not enlarged at the angle. The longest gill rakers nearly half as long as eye; 22 or 23 of them on the anterior limb of arch.

Scales ctenoid; snout, mandible, maxillary, and the greater part of preorbital naked. Dorsal and anal naked; a very slight scaly sheath at the base of each; that of anal a little the better developed. Ventrals, pectorals, and caudal with a few scales on base; fine scales running nearly to the tips of caudal rays.

Pectoral $1 \frac{1}{10}$ to $1 \frac{1}{5}$ in the length of head; reaching to a point midway between tips of ventrals and front of anal. Third and fourth dorsal spines equal and the highest; their length $2 \frac{1}{2}$ to $2 \frac{3}{4}$ in head; behind these the spines gradually and uniformly decrease in length to the soft dorsal. Base of soft dorsal from $1 \frac{4}{5}$ to 2 in head. The anterior or longest rays of soft dorsal equal in length to those of anal and a little greater than the diameter of eye. The anal ends slightly in front of the soft dorsal. Ventrals reaching halfway from their base to front of anal. Caudal forked; the upper lobe a little longer than lower.

Color greenish gray on back; sides and belly silvery, overlaid with dusky shades. The scales on sides have a darker border, and faint traces of longitudinal streaks follow the rows of scales. Base of pectoral with a dark spot above on both sides of fin; axil dusky; inner surface of fin usually darker than outer surface. Ventrals dark, and growing darker toward their tips. Dorsals dusky; the spinous dorsal sometimes black; the rays of soft dorsal and anal similar, growing darker toward tips.

This species differs from Isacia conceptionis in having a larger eye, a longer head, the lower jaw a little thinner at the tip and slightly less projecting, and the vertical limb of the preopercle more concave. The color is everywhere lighter in the specimens at hand, though the markings are the same.

In the description given by Abbott (quoted above) the measurement given for the length of the head is incorrect. It is $2 \frac{9}{10}$ in entire length to base of caudal in his smaller specimen and $3 \frac{1}{10}$ in his larger one. Cuvier and Valencienries say that the length of the head of Isacia conceptionis is less than the depth. It is constantly greater than the depth in Isacia venusta, and slightly less, or equal to the depth in our specimens of the former species.

Four specimens collected at Callao, Peru. Besides these there are in the Stanford University collections two specimens from the same locality collected by Admiral Beardslee. The specimens range from 175 to $250 \mathrm{~mm}$. in length. A specimen $220 \mathrm{~mm}$., collected by Mr. Simons, is selected as the type. It is Cat. No. 53467, in the U. S. National Museum. Other specimens are in Stanford University museum. 
62. POMADASIS BURRO, new species.

Plate LXV, fig. 3.

Head, $2 \frac{3}{5}$ to $2 \frac{1}{2}$ in length to base of caudal; depth, $2 \frac{2}{3}$. Eye, 5 to $5 \frac{1}{2}$ in head; snout, $2 \frac{7}{8}$; maxillary, $3 \frac{1}{3}$ to $3 \frac{1}{2}$; interorbital space, $4 \frac{3}{4}$; fourth dorsal spine, 3 to $3 \frac{1}{4}$; second anal spine, $2 \frac{3}{4}$. Dorsal, XI, I, 13 ; anal, III, 8. Scales, 47.

Upper anterior profile concave above eyes; that of snout straight and long. Edge of preopercle without trace of serrations; opercle with a broad dermal flap. Maxillary reaching to or slightly behind the vertical from anterior nostril. Lips thick and spongy; lower jaw a little projecting. Gill rakers rather thick, one-fourth of diameter of eye; 15 developed on anterior limb of arch.

Pectoral reaching to opposite vent; ventrals three-fourths or distance from their base to vent. Second anal spine a little shorter than soft rays, near its tip it tapers quickly to a point that is not very acute.

This species has the general characters of $P$. macracanthus, but differs in having no serrations on edge of preopercle, in having shorter dorsal spines, a slightly shorter and much more slender second anal spine, and the head and maxillary longer.

We have numerous specimens of $P$. macracanthus from Mexico and Panama in the Stanford University collections for comparison; the largest equal in size to the larger specimen of $P$. burro. All of them have the preopercle sharply denticulated, the large ones showing no decrease in the size or sharpness of the denticulations.

Two specimens were collected at Guayaquil, 26 and $31 \mathrm{~cm}$. in length. The larger one is the type and is Cat. No. 53468, U. S. National Museum. The cotype is in Stanford University museum.

Burro, the vernacular name in Central and South America of different species of Pomadasis. They make a noise when caught resembling the noise made by a "burro" or donkey.

Table of measurements in hundredths of length.

\begin{tabular}{|c|c|c|c|c|c|c|}
\hline Species.... & \multicolumn{2}{|c|}{$\begin{array}{c}\text { Pomadasis } \\
\text { burro. }\end{array}$} & \multicolumn{4}{|c|}{ Poimadasis macracanthus. } \\
\hline Locality . & Guay & iil. & Panama. & $\begin{array}{l}\text { Mazat- } \\
\text { lan, } \\
\text { Mexico. }\end{array}$ & Guas & $\begin{array}{l}\text { as, } \\
\text { o. }\end{array}$ \\
\hline Length in millimeters to base of r.audal......... & 215 & 260 & 214 & 258 & 222 & 200 \\
\hline 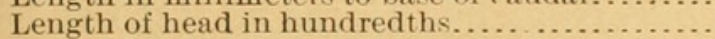 & 42 & 41 & 37 & 37 & 37 & 38 \\
\hline 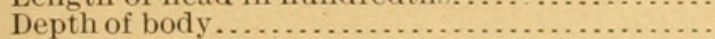 & 37 & 38 & 38 & 36 & 35 & 36 \\
\hline 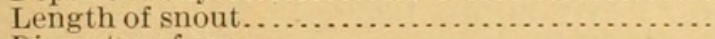 & 14 & 14 & 12 & 14 & 14 & 14 \\
\hline 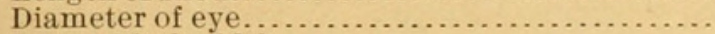 & 8 & $7 \frac{1}{2}$ & $7 \frac{1}{2}$ & 7 & 7 & 7 \\
\hline Interorbital width $\ldots \ldots \ldots \ldots \ldots \ldots \ldots \ldots \ldots \ldots \ldots \ldots \ldots \ldots$ & 9 & 9 & $8 \frac{1}{2}$ & $8 \frac{1}{2}$ & $8 \frac{1}{2}$ & \\
\hline 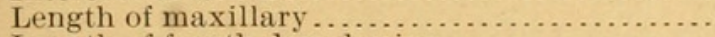 & 12 & $12 \frac{1}{2}$ & 11 & $10 \frac{1}{2}$ & 11 & 11 \\
\hline Length of fourth dorsal spine ................. & 15 & 14 & 17 & $18^{2}$ & 17 & 18 \\
\hline Length of second anal spine................. & 16 & 15 & 18 & 18 & 17 & 17 \\
\hline 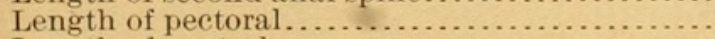 & 29 & 30 & 33 & 28 & 29 & 28 \\
\hline 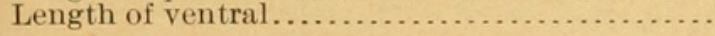 & 22 & 22 & 21 & 22 & 21 & 21 \\
\hline
\end{tabular}




\section{Family GERRID E.}

\section{EUCINOSTOMUS CALIFORNIENSIS (Gill).}

Two specimens from Guayaquil, Ecuador.

64. GERRES PERUVIANUS Cuvier and Valenciennes.

Several specimens were taken at Guayaquil, differing from specimens from Panama only in being darker in color.

\section{Family KYPHOSID E.}

\section{DOYDIXODON LÆVIFRONS (Tschudi).}

Plate LXVI, fig. 2.

A single specimen from Molendo, Peru, $27 \mathrm{~cm}$. in length.

This species may be known from $D$. freminville $i^{a}$ by the produced anterior rays of the soft dorsal forming an angle, which when depressed reaches to the tip of the last dorsal ray. The fourth ray is the longest and forms the tip of the angle, behind which the posterior margin of the fin is strongly concave.

In D. freminvillei (specimens from the Galapagos Islands in the Stanford University collections) the soft dorsal is not angulated; the tip of the fourth ray is opposite the beginning of the last two-fifths or one-third of the base of the fin. The fin is usually rounded and everywhere convex as shown in the accompanying figure, but its margin may sometimes form a sigmoid curve, convex in front and concave behind, and nowhere angulated except at tip of last ray. The latter condition is shown in Valenciennes' plate, ${ }^{b}$ and in the largest of our specimens, $45 \mathrm{~cm}$. in length, but the fourth ray is little if any longer than when the fin is everywhere convex. This condition is probably developed with age.

The anterior rays of the anal of D. lævifrons are longer than in the other species, making the posterior margin of the fin more oblique.

Perhaps a greater difference than these is shown in the size of the teeth, which in D. lavifrons are nearly twice as large as in D. freminvillei, and are in fewer rows. In the former species they are in 5 oblique series, on the mandible, running downward and inward toward the symphysis. In D. freminvillei they are in 9 oblique series.

The dorsal of our specimen of $D$. lævifrons has 15 rays. Of the 16 specimens of $D$. freminvillei counted, 10 of them have 17 rays, 4 have 18 rays, and 2 have 16 rays. This is opposite to the condition alleged to exist. Tschudi counts 18 rays in the type of D. Trevifrons from Huacho, Peru, and Valenciennes counts 15 rays in the type of $D$. 
freminvillei from the Galapagos. The plate published by Valenciennes, however, proves our Galapagos specimens to be $D$. freminvillei by the teeth and shape of the dorsal.

\section{Family SCI ENID A.}

\section{ARCHOSCION ANALIS (Jenyns).}

A specimen collected at Callao, Peru, the type locality of the species. 67. CYNOSCION ALBUS (Günther).

A small specimen from Guayaquil, agreeing well with Panama specimens.

\section{BAIRDIELLA CHRYSOLEUCA (Günther).}

Three specimens from Guayaquil differ slightly from specimens from Panama. The anal rays are 7 in one specimen and 8 in the other two (9 in Panama specimens). There is a considerably longer distance between the tips of the anal rays and the base of the caudal in the former specimen, and a slightly longer distance between these points in the other two than in the specimens from Panama. As usual, the Guayaquil specimens are much darker. No other difference is appreciable, however, and these differences will probably be found to fall within the range of variation of the species.

69. BAIRDIELLA ENSIFERA (Jordan and Gilbert).

A couple of specimens from Guayaquil, Ecuador, differ from Panama specimens only in being darker.

\section{STELLIFER MINOR (Tschudi).}

A single specimen collected at Callao, Peru. The head in this species is far less cavernous than in other members of the genus Stellifer.

\section{SCI $Æ N A$ FASCIATA (Tschudi).}

One small specimen $15 \mathrm{~cm}$. in length from Callao, Peru.

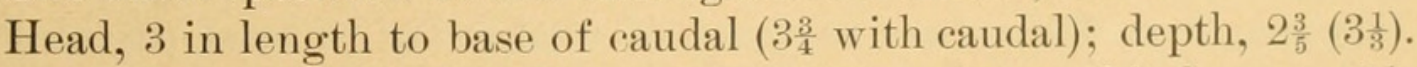
Eye, $4 \frac{1}{2}$ in head, scarcely shorter than snout; interorbital space, $3 \frac{1}{2}$;

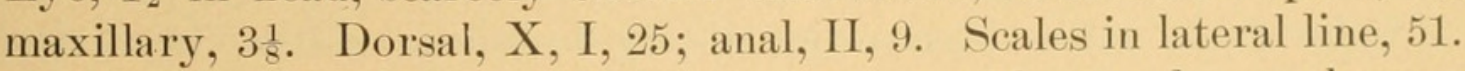

Body very deep and compressed; the snout blunt and scarcely projecting over the mouth. Maxillary reaching a little past middle of eye. Mouth slightly oblique; lips papillose. Teeth fine, in bands, the outer series only slightly enlarged. Border of preopercle with very small membranous serræ. Gill rakers very small; only 7 developed on lower limb of arch.

Scales exceedingly sharply ctenoid, each with a broad boreer of sharp, fine corrugations which involves nearly the whole surface of the scale; each corrugation ending in a fine point. Tip of snout and 
mandible naked. Lower half of soft dorsal closely covered with fine scales forming a rather thick sheath.

Third dorsal spine the longest, its length $2 \frac{3}{5}$ in head; the succeeding spines decrease rapidly in length, making the fin triangular. Pectoral short, $1 \frac{1}{2}$ in head, scarcely extending to tips of ventrals, which reach two-thirds of distance from their base to front of anal. Second anal spine stout, but not over three-fourths the length of first anal ray; length of second spine 3 in head. Tips of anal rays reach to below base of last dorsal ray. Caudal slightly S-shaped, the upper lobe the longer; tip of lower angle rounded.

Color dark on sides and back; lower parts dirty silvery. A conspicuous, rather narrow, light band runs downward and slightly obliquely backward from between the dorsals nearly to vent. A similar short band runs from middle of soft dorsal, but does not reach to lateral line. The opercle ends in a broad flap, which is coal black much as in some of the centrarchoid fishes. The fins are all black.

\section{SCI $Æ N A$ DELICIOSA (Tschudi).}

This is the best represented Sciænoid fish in the collection. Many specimens were collected at Callao, and one at Molendo, Peru.

Head, $2 \frac{3}{4}$ to 3 in length to base of caudal; depth, $3 \frac{1}{5}$ to $3 \frac{2}{5}$. Eye, $5 \frac{1}{2}$ to 6 in head; interorbital space, $3 \frac{3}{4}$; snout, $3 \frac{4}{5}$ to 4 ; maxillary, 3 . Dorsal, IX or X, I, 22 or 23; anal, II, 10 . Scales, 50 (pores).

Upper anterior profile forming an even curve from nape to snout. Snout projecting beyond tip of mandibile in a variable degree as in related species, or from $\frac{1}{2}$ to 1 diameter of pupil. Viewed laterally its profile usually forms a semicircle, but in one or two specimens it-is a little angulated at the tip. Gill rakers scarcely as long as diameter of pupil; $6+12$ or 13 in number.

The fourth dorsal spine the highest, $2 \frac{3}{4}$ in head. The last spine of first dorsal is half as long as the spine of the second dorsal, and is attached to it by a membrane. Tip of pectoral reaching 1 diameter of eye past notch between dorsals. Ventrals reaching one-half of distance from their base to front of anal. Tip of anal reaching to below base of last dorsal ray. Caudal lunate.

Color dusky on back, growing silvery on sides. Rather faint, dark lines following the rows of scales; axil dark.

\section{SCI $Æ N A$ GILBERTI, new species.}

Plate LXVI, fig. 3.

Head, $3 \frac{2}{5}$ to $3 \frac{1}{5}$ in length to base of caudal; ( 4 to $3 \frac{5}{6}$ in entire length); depth, $3 \frac{8}{4}$ to $3 \frac{1}{2}$. Eye, $9 \frac{1}{2}$ to 11 in head; interorbital space,

a The measurement appearing first is of the smaller of our two specimens; where only one measurement is given the specimens do not differ. 
$3 \frac{1}{4}$ to $3 \frac{1}{2}$; snout, 4 ; maxillary, $2 \frac{1}{2}$. Dorsal, X, I, 24 to X, I, 21; anal, II, 10. Scales, 66; counting subvertical series there are 10 scales from front of dorsal to lateral line, and 13 from front of anal to lateral line.

Anterior profile gently curved a short distance in front of dorsal, thence appearing perfectly straight to near tip of snout, where it again slightly curves downward. Head very broad, with a broad evenly curved interorbital space, 3 to $3 \frac{1}{2}$ times the diameter of eye. Jaw nearly even in small specimen; the lower included in the large one. Small teeth in 2 or 3 irregular rows in upper jaw, with an outer series of much enlarged ones; the length of the latter equal to diameter of anterior nostril. A row of similar enlarged teeth on lower jaw, and an irregular row of smaller teeth outside of them, fitting close against them. No canines present. Maxillary reaching to a little past anterior border of eye. Anterior nostril small and round; the posterior 3 times as long as wide. Gill rakers 3 or $4+10$; the longest threefourths diameter of eye. Edge of preopercle with rather sharp denticles somewhat enlarged toward angle.

Pectoral short; equal in length to ventral; $2 \frac{1}{4}$ in head. Third, fourth, and fifth dorsal spines highest, equal to combined length of snout and eye; tip of third reaching to base of eighth when fin is depressed. The membrane of the next to the last spine scarcely reaches to the base of the last spine, which is a trifle longer than the former, and is attached by a membrane to the soft rays. Base of soft dorsal seven-eighths length of head; its highest rays equal to snout and half eye. Anal spines rather weak, but not flexible; the second spine half the length of the first ray, which is scarcely so long as the second ray; tip of longest ray reaching to tip of last ray when fin is depressed, or to under base of last dorsal ray. Caudal lunate, the middle rays 2 in head, the upper rays $1 \frac{1}{2}$ in the smaller specimen. In the larger specimen the caudal is much more deeply lunate, the upper lobe longer and sharper than the lower; extending $1 \frac{1}{2}$ times diameter of eye past middle rays. Scales ctenoid; the entire head, except the tip of mandible, and lips covered with irregular scales. Dorsal and anal fins naked except a narrow definite area at extreme base. Pectoral with a few scales on base. Caudal with small scales on membrane extending considerably over half the distance from base to tips of rays; a series of small scales carrying lateral line to edge of caudal.

Color dusky on top of head and back, becoming silvery below. Dark lines follow the rows of scales on back and sides. These are scarcely noticeable on the smaller specimen, and not very conspicuous on the larger. Dorsals dusky; caudal and pectoral slightly dusky; anal with a very little dusky color on membrane; ventrals white; inside of opercle dusky. 
This species differs from S. wieneri Sauvage in having the length of head greater than the depth, and longer as compared with the entire length; the snout shorter as compared with the interorbital space; the eye smaller; the caudal lunate, and the scales larger. Our smaller specimen approaches $S$. wieneri in size of eye and shape of caudal more nearly than our larger one, though the specimen from which Sauvage drew his description was considerably larger than our large one.

The following, extracted from Sauvage's description, will show the degree of difference between these two species: Depth equal to length of head, which is contained $4 \frac{2}{3}$ in total length. Snout equal to interorbital space. Eye, 2 in snout; $7 \frac{1}{2}$ in head. Caudal, truncate. Lateral line, 85. Length, $57 \mathrm{~cm}$.

Two specimens were collected at Callao, Peru, respectively 30 and $45 \mathrm{~cm}$. in length. The latter is the type. It is deposited in the U. s. National Museum, Cat. No. 53464.

The cotype is in Stanford University museum.

I take pleasure in naming this species for Dr. C. H. Gilbert, to whom I owe the best of my ichthyological training.

\section{POLYCLEMUS PERUANUS Steindachner.}

A single specimen from Callao, Peru, agrees very well with Doctor Steindachner's description of the type.

Head equals depth, $3 \frac{2}{5}$ in length without caudal. Eye $6 \frac{1}{2}$ in head; interorbital space, $2 \frac{5}{6}$; snout, $3 \frac{5}{6}$; maxillary, $3 \frac{1}{3}$; longest dorsal spine, 2; second anal spine, 4; longest soft anal ray, 2. Dorsal, X, I, 23; anal, II, 8. Scales of lateral line, 55 .

This specimen does not show the dusky cross bands described by Jordan and Eigenmann from cotypes of the species in the Museum of Comparative Zoology. ${ }^{a}$

They describe the snout as being $4 \frac{2}{5}$ in length of head; and the eye $4 \frac{2}{3}$. The specimen at hand agrees better with Doctor Steindachner's description (Schneuzenlänge nicht ganz 4 mal; Augendiameter bei erwachsenen individuen nahezu 6 mal). "Caudal fin slightly lunate or S-shaped " does not adequately describe its shape. The lower half of the fin is obliquely truncate, the upper half lunate, thus leaving the fin angulated at the middle rays, which are as long as the angulated upper lobe.

\section{MICROPOGON ALTIPINNIS Günther.}

A small specimen was collected at Guayaquil, Ecuador, which agrees in all essential characters with specimens from Panama. In comparing this species directly with $M$. ectens Jordan and Gilbert, it can be known at once by the enlarged scales on the side behind the pectoral

$a$ Rept. U. S. Fish Comm., 1886, p. 415.

$b$ Jordan and Eigenmann, Rept. U. S. Fish Comm., 1886. 
and below the lateral line. There are three more scales counting the subvertical series between the median line of belly and lateral line in M. altipinnis than in M. ectens though the difference appears greater than the actual count indicates.

The occurrence of $M$. ectens at Panama may here be recorded. There is a specimen of this species in the Stanford University collections taken at Panama by the U. S. Bureau of Fisheries steamer Albatross, which has hitherto been identified with $M$. altipennis. It agrees in all respects with specimens of the former species from Mazatlan, Mexico.

76. CHILODACTYLUS VARIEGATUS Cuvier and Valenciennes.

Several specimens were collected at Callao. They all have the dorsal spines 17 in number, not 16 as recorded in the original description. The soft dorsal has from 29 to 31 rays, and the anal 9 or 10 . The swollen lower rays of the pectoral number 6 ( 7 in original description), and extend from $\frac{1}{2}$ to 1 diameter of the pupil beyond the branched rays. The gill rakers are rather slender, and number 12 or 13 on lower limb of arch.

\section{Family CICHLID A.}

\section{7. ÆQUIDENS RIVULATUS (Günther).}

Several specimens taken at the market in Guayaquil and one at Eten, Peru. The longest $16 \mathrm{~cm}$. in length.

Head, $2 \frac{1}{2}$ to $2 \frac{3}{4}$ in length to base of caudal; depth, $2 \frac{1}{4}$. Eye, $3 \frac{1}{2}$ to 4 in head in specimens from 7 to $9 \mathrm{~cm}$. in length; 4 to $4 \frac{1}{2}$ in specimens from 11 to $16 \mathrm{~cm}$. in length; maxillary, 3 to $3 \frac{1}{4}$; snout, $2 \frac{1}{2}$ to $2 \frac{3}{4}$. Dorsal, XIV (occasionally XIII), 10 or 11; anal, III, 8 or 9 . Scales, 26 or $27 ; 3$ between front of dorsal and lateral line, 7 between front of anal and upper part of lateral line. Gill rakers, $3+8$ or 9 .

Small specimens up to $10 \mathrm{~cm}$. in length have the anterior profile of head straight or slightly convex; large specimens, from 14 to $16 \mathrm{~cm}$. in length usually have it slightly concave. Interorbital space increasing in width and growing more nearly flat with age; in large specimens its width is contained $2 \frac{3}{5}$ times in head; in small specimens 3 times. Length of dorsal and anal rays increasing with age; the longest ones 1 to $1 \frac{1}{5}$ in head in large specimens, and reaching past middle of caudal rays; $1 \frac{1}{2}$ in small specimens and not reaching to middle of caudal rays. Small specimens have the dark lateral spot much more conspicuous, and the dark lines radiating from eye to snout and across cheek much less conspicuous. They have narrow cross bars which are scarcely to be seen on specimens $13 \mathrm{~cm}$. in length, and not at all on larger ones. These are placed as follows: One at base of caudal rays; one across caudal peduncle just behind soft dorsal; one under middle of soft dorsal; one just behind lateral spot; one just in front 
of lateral spot; sometimes a faint trace of one under fourth or fifth dorsal spine. Body and fins of large specimens darker than in small ones, and more or less conspicuous, broken, longitudinal stripes follow the rows of scales on sides. The specimen from Eten, Peru, differs from the others in having the lower part of the head coal black up to a level with the mouth.

\section{Family POMACENTRIDA.}

78. CHROMIS CRUSMA Cuvier and Valenciennes.

Two specimens from Callao, Peru.

\section{Family EPHIPPID A.}

\section{CHÆTODIPTERUS ZONATUS (Girard).}

One specimen from Guayaquil, Ecuador.

80. PARAPSETTUS PANAMENSIS Steindachner.

Three specimens from Guayaquil differ from specimens from Panama only in being everywhere much darker.

\section{Family BALISTIDÆ.}

\section{BALISTES NAUFRAGIUM Jordan and Starks.}

Six specimens from 15 to $17 \mathrm{~cm}$. in length were obtained at Guayaquil, Ecuador. They agree in number of scales, fin rays, and proportions with specimens from Panama, but are much rougher. The first dorsal spine is more thickly set with spinules, making it thicker. The soft fin rays are constantly 26 in the dorsal and 24 in the anal. $B$. adspersus Tschudi, as described, has 24 rays in the dorsal and 20 in the anal, besides differing in depth, coloration, and minor characters. In these small specimens of $B$. naufragium and in specimens from Panama of a similar size the eyes are connected across the interorbital space by two narrow dark bars; one between the posterior orbital margins and one somewhat behind the anterior margins.

\section{Family TETRAODONTIDA.}

\section{SPHEROIDES FURTHI (Steindachner).}

Four specimens 4 to $9 \mathrm{~cm}$. in length from Guayaquil, Ecuador, seem to be referable to this species. It may be distinguished from other west coast species of this genus by the large eye as compared with the interorbital space and length of snout.

Head, 245 to 3 in length to base of caudal. Eye, $3 \frac{3}{4}$ to 4 in head; interorbital space (bone) equal to eye; snout, $2 \frac{1}{3}$ to $2 \frac{1}{2}$. Dorsal, 8; anal, 7 . 
Body short and stout; snout rather steep and slightly concave in profile. Prickles sharp and rather closely set on back from between front of eyes to within half a diameter of eye of dorsal. Patch of prickles on ventral sc face covering a larger area; extending from a little in front of eyes to vent, sending a triangular area up between eye and gill opening nearly to dorsal patch; not extending above lower rays of pectoral on side of body. Entire side otherwise naked; no prickles on body behind vent. Caudal slightly lunate; the angles sharp.

Color dark brown on back and upper part of sides; mottled on sides by spots and bars running irregularly more or less obliquely. No color on area of prickles on ventral surface. The very small specimens show slightly the crossbars on back described by Steindachner in the original description. Base of pectoral dusky, but no dark band is present as described. Fins without markings.

\section{Family GOBIID A.}

\section{PHILYPNUS LATERALIS Gill.}

Two specimens obtained at Guayaquil, Ecuador, and one at Eten, Peru; the largest $23 \mathrm{~cm}$. in length.

The coloration of these specimens is scarcely so brilliant as in specimens of $P$. dormitator from the West Indies, though the contrary condition is alleged to exist. The scales number from 54 to 56 , and the anal has constantly 11 rays.

\section{ELEOTRIS PICTA Kner and Steindachner.}

Two large specimens were preserved from Guayaquil. They are black or very dark brown on upper parts and a clearer slightly lighter brown below, but with no white anywhere. The usual flecks of white on ventral parts so conspicuous in specimens from more northern localities, are at these only slightly lighter than the surrounding color and not noticeable. The fins are all black mottled with light gray, and the spinous dorsal has a light border. They do not otherwise differ from specimens from Lower California.

\section{MAPO SOPORATOR (Cuvier and Valenciennes.)}

Specimens from Payta, Peru; and Guayaquil, Ecuador.

\section{GOBIONELLUS SAGITTULA (Günther).}

Four small specimens from Guayaquil, Ecuador. They do not differ from specimens from the coast of Mexico, and San Diego, California, except in having the middle rays of the caudal a little longer.

Family MALACANTHID \&.

87. CAULOLATILUS PRINCEPS (Jenyns).

Four specimens from Callao, Peru. 


\section{Family BATRACHOIDIDA.}

\section{BATRACHOIDES PACIFICI (Günther).}

Specimens from Guayaquil, Ecuador.

\section{Family BLENNIID A.}

89. LABRISOMUS PHILIPPI (Steindachner).

Six specimens from Callao have the fin formulæ as follows: Dorsal, XIX, 13; anal, II, 19 in four specimens; dorsal, XIX, 12; anal, II, 19 in one specimen; dorsal, XVIII, 13; anal, II, 18 in one specimen. There is considerable discrepancy between our specimens and the original description in the size of the eye. The type was nearly 10 inches long and the eye was said to be $4 \frac{2}{3}$ in head, and $1 \frac{1}{2}$ in snout. In our specimens from 10 to 12 inches long the eye is from 6 to $6 \frac{1}{2}$ in head, and from 2 to $2 \frac{1}{4}$ in snout. In a specimen 7 inches long the eye is $5 \frac{1}{2}$ in head and $1 \frac{3}{4}$ in snout.

In some specimens light-blue spots and reticulations remain on the side of the head below the eye in addition to the dark-brown spots.

\section{HYPLEUROCHILUS PAYTENSIS (Steindachner).}

Two specimens were taken from rock pools at Payta, Peru, the type locality. They have 20 anal rays (one less than described for the type) and 17 and 15 dorsal rays, respectively (the type had 17).

\section{Family PLEURONECTID A.}

\section{PARALICHTHYS ADSPERSUS (Steindachner).}

One large specimen from Callao, Peru.

92. CITHARICHTHYS GILBERTI Jenkins and Evermann.

One specimen from Guayaquil is very dark brown in color but otherwise not different from specimens from Panama.

The scales on the eyed side of this species might better be described as finely ctenoid than ciliated. 


\section{$2 \mathrm{BHL}$ Biodiversity Heritage Library}

Starks, Edwin Chapin. 1906. "On a collection of fishes made by P. O. Simons in Ecuador and Peru." Proceedings of the United States National Museum 30(1468), 761-800. https://doi.org/10.5479/si.00963801.30-1468.761.

View This Item Online: https://www.biodiversitylibrary.org/item/53722

DOI: https://doi.org/10.5479/si.00963801.30-1468.761

Permalink: https://www.biodiversitylibrary.org/partpdf/53143

\section{Holding Institution}

Smithsonian Libraries

\section{Sponsored by}

Smithsonian

\section{Copyright \& Reuse}

Copyright Status: Public domain. The BHL considers that this work is no longer under copyright protection.

This document was created from content at the Biodiversity Heritage Library, the world's largest open access digital library for biodiversity literature and archives. Visit BHL at https://www.biodiversitylibrary.org. 